\title{
Interactions Among Ecosystem Services Across Land Uses in a Floodplain Agroecosystem
}

\author{
María R. Felipe-Lucia ${ }^{1}$, Francisco A. Comin $^{2}$ and Elena M. Bennett ${ }^{3}$
}

\begin{abstract}
Managing human-dominated landscapes such as agroecosystems is one of the main challenges facing society today. Decisions about land-use management in agroecosystems involve spatial and temporal trade-offs. The key scales at which these tradesoffs occur are poorly understood for most systems, and quantitative assessments of the services provided by agroecosystems under different combinations of land uses are rare. To fill these knowledge gaps, we measured 12 ecosystem services (ES), including climate regulation, gas regulation, soil stability, nutrient regulation, habitat quality, raw material production, food production, fishing, sports, recreation, education, and social relationships, in seven common land-use types at three spatial scales, i.e., patch, municipality, and landscape, in a riparian floodplain in Spain. We identified the provision of each ES in each land-use type either by direct measurement or from public databases. We analyzed the interactions, i.e., trade-offs and synergies, among ES across land uses and spatial scales and estimated ES provision in several land-use change scenarios. Our results illustrated that each land-use type provides unique bundles of ES and that the spatial scale at which measurements were taken affected the mixture of services. For instance, a land-use type with low provision of services per hectare but with an extensive area can supply more services to the overall landscape than a land-use type supplying higher values of services per hectare but with a smaller extent. Hence, riparian forest supplied the most service of any landuse type at the patch scale, but dry cereal croplands provided the most services across the municipality and landscape because of their large area. We found that most ES should be managed primarily at the patch scale, but food production, fishing, and social relationships were more relevant to manage at the municipality scale. There was great variability in ES interactions across scales with different causes of trade-offs at each scale. We identified more significant synergies among ES than trade-offs. Trade-offs were originated because some services were mutually incompatible within a given land use, whereas the provision of others depended on land-management decisions within a land-use type. Thus, we propose a classification of ES interactions that incorporates societal values as drivers of management decisions along with biophysical factors as likely causes of ES trade-offs and conclude with practical suggestions to reduce trade-offs and to enhance the supply of multiple ES to society.
\end{abstract}

Key Words: agroecosystem; ecosystem services; floodplain; interactions; land uses; spatial scales; trade-offs

\section{INTRODUCTION}

Agroecosystems are managed to fulfill basic human needs, such as food and raw materials (Zhang et al. 2007). They occupy $40 \%$ of the global terrestrial surface (FAO 2009, as cited in Power 2010), of which $3.5 \%$ are on floodplains (Tockner and Standford 2002). Floodplains sustain a large portion of the world's food production thanks to their nutrient-rich and water-abundant soils. Indeed, great parts of floodplains' extent are dedicated to agricultural production, from $11 \%$ in African rivers to $79 \%$ in European rivers (Tockner and Standford 2002). Current pressure on floodplain agroecosystems to feed the growing human population is leading to major environmental degradation, including deforestation, soil erosion, nutrient leaching and water abstraction, diversion, and pollution (Simoncini 2009). This is especially important given that floodplains are one of the most endangered habitats and biodiversity hotspots while still the second highest worldwide attraction for housing developers (Moss and Monstadt 2008). Floodplains are key ecosystems for land managers because of their important role in food supply, human settlement, and biodiversity conservation.

Decisions about land-use planning, in floodplains and elsewhere, generally involve spatial and temporal trade-offs for society and ecosystems (Box 1). Consequences of these trade-offs need to be assessed across temporal and spatial scales by policy makers prior to management actions such that managers can make effective decisions (Rodríguez et al. 2005, 2006, Tallis and Polasky 2009, Cabell and Oelofse 2012). Such assessments are paramount to maximizing human well-being, enabling adaptive management, and improving resilience in the social-ecological system (Carpenter et al. 2005). The spatial patterns of social-ecological systems, e.g., the number, location, and relative proportion of different land-use types, can vary at differing spatial scales, which can then influence ecological functions (Pringle et al. 2010). Repercussions of outcomes at a particular spatial scale may affect biodiversity and ecosystem conservation, as well as stakeholder interests and institutional responsibilities (Hein et al. 2006). Thus, to make effective land-management decisions, baseline data about the biophysical and social settings are required at the spatial scales of the decisions being made (DeFries et al. 2004, Nicholson et al. 2009). Effects of management actions may have different results across spatial scales (Concepción et al. 2012), e.g., at the individual patch level compared to a municipality, or entire landscape. Therefore high quality local data and multiscale analyses are fundamental to design adequate management plans, understand the trade-offs they encompass, and facilitate decision making (Carpenter et al. 2009).

To orient decision makers to identifying trade-offs and synergies in land-use planning, many studies have applied the concept of

${ }^{1}$ Instituto Pirenaico de Ecología-CSIC., ${ }^{2}$ Instituto Pirenaico de Ecología-CSIC, ${ }^{3}$ Department of Natural Resource Sciences and McGill School of Environment, McGill University 
Table 1. Municipalities, number of inhabitants, and extent of each municipality within the floodplain of the Piedra River valley.

\begin{tabular}{|c|c|c|c|c|}
\hline Municipality & $\begin{array}{l}\text { Number of } \\
\text { inhabitants }\end{array}$ & Total area $\left(\mathrm{km}^{2}\right)$ & $\begin{array}{l}\text { Area within the } \\
\text { floodplain }\left(\mathrm{km}^{2}\right)\end{array}$ & $\begin{array}{l}\% \text { of land within the } \\
\text { floodplain }\end{array}$ \\
\hline Aldehuela de Liestos & 52 & 38.04 & 1.13 & 2.97 \\
\hline Campillo de Dueñas & 92 & 60.63 & 0.56 & 0.93 \\
\hline Carenas & 195 & 31.22 & 2.87 & 9.19 \\
\hline Castejón de las Armas & 121 & 16.19 & 0.78 & 4.84 \\
\hline Cimballa & 127 & 31.95 & 1.51 & 4.72 \\
\hline Embid & 53 & 36.2 & 2.09 & 5.79 \\
\hline Monterde & 190 & 55.94 & 2.06 & 3.68 \\
\hline Nuévalos & 355 & 41.84 & 3.39 & 8.11 \\
\hline Rueda de la Sierra & 51 & 51.02 & 1.67 & 3.28 \\
\hline Torralba de los Frailes & 94 & 59.22 & 0.82 & 1.38 \\
\hline Torrubia & 24 & 28.18 & 1.38 & 4.91 \\
\hline Tortuera & 185 & 82.21 & 1.06 & 1.29 \\
\hline Total & 1539 & 532.64 & 19.33 & 3.63 \\
\hline
\end{tabular}

Modified from Instituto Aragonés de Estadística (Padron Municipal of Inhabitants), updated on 1 January 2011 and from Instituto Nacional de Estadística (Municipal surface), updated on 1 January 2008.

ecosystem services (ES; Costanza et al. 1997, de Groot et al. 2002), i.e., the benefits humans obtain from ecosystems, such as clean air, water, food, raw materials, and recreation (Rose and Chapman 2003, Bennett and Balvanera 2007, Barral and Maceira 2012, Rathwell and Peterson 2012). The amount of each ES supplied in a given area depends on both the per hectare provision of service by land-use type and the total amount of each land use found in the study area. Moreover, ES do not operate independently from each other (Pereira et al. 2005), but they interact in trade-offs and synergies. There is also evidence that ES act differently across both spatial and temporal scales (Swift et al. 2004, Rodríguez et al. 2005, Power 2010), and that land-use patterns affect ES provision (Mitchell et al. 2013); however, the key scales for ES management still remain poorly understood (Hein et al. 2006). Most studies of multiple ES use GIS and satellite images (Kreuter et al. 2001, Konarska et al. 2002, Chen et al. 2009), global databases (Viglizzo and Frank 2006, Tianhong et al. 2010), or models to estimate ES provision (Nelson et al. 2009, Goldstein et al. 2012). Few studies however, have gathered local data across land uses (but see Raudsepp-Hearne et al. 2010), despite evidence that these data are critical to accurate assessment of service provision (Eigenbrod et al. 2010).

Floodplains contribute to the provision of more than $25 \%$ of all terrestrial ES (Tockner and Standford 2002). Therefore, understanding ES interactions in floodplain agroecosystems is an important challenge in ecology. Understanding how floodplains can be managed across spatial scales to deliver multiple ES could enhance the supply of ES to society, providing land managers with decision-making tools to reach win-win or small loss-big gain solutions (DeFries et al. 2004) for policy making.

We aim to identify: (1) how the supply of a set of ES changes across land-use types and spatial scales in a floodplain; (2) which trade-offs and synergies are common or different in each landuse type and across spatial scales; and (3) how land-use change might affect the provision of ES. We evaluated $12 \mathrm{ES}$ in 7 landuse types identified within a river floodplain at multiple spatial scales, i.e., patch, municipality, and landscape, using ecological indicators. We illustrate significant differences in the supply of ES across land uses, spatial scales, and alternative scenarios; and we analyze their interactions, i.e., trade-offs and synergies. Finally, we discuss major questions on ES interactions and suggest practical land-use management applications.

Box 1. Definitions applied to ecosystem services.

Trade-off: Situation in which land use or management actions increase the provision of one ecosystem service and decrease the provision of another. This may be caused by simultaneous responses to the same driver or caused by true interactions among services (Bennett et al. 2009).

Synergy: Situation in which the combined effect of a number of drivers acting on ecosystem services is greater than the sum of their separate effects (adapted from Carpenter et al. 2005). In other words, a synergism occurs when ecosystem services interact with one another in a multiplicative or exponential fashion (Rodríguez et al. 2006). These can be positive, i.e., multiple services improving in provision, or negative, i.e., multiple services declining in provision.

\section{METHODS}

\section{Study site}

The study area is the floodplain of the Piedra River in central Spain (Fig. 1). The Piedra River is $76 \mathrm{~km}$ long and the watershed covers an area of $922.72 \mathrm{~km}^{2}$. The river floodplain ranges from 50 to 300 $\mathrm{m}$ wide and occupies $19.3 \mathrm{~km}^{2}$. It is composed of 12 municipalities in which 1539 people live permanently (Table 1), although the population can double during the summer (Felipe-Lucia 2012). The floodplain is commonly split into three parts, i.e., upper, central, 
Table 2. Selected ecosystem services, abbreviations used in following tables and figures, indicators used for their evaluation, units in which they were measured, and data source (See Appendix 1 for detailed information on the data source, indicators used, and units).

\begin{tabular}{|c|c|c|c|c|c|}
\hline ES Group & Ecosystem Service & ES abbrev. & Indicator & Unit & $\begin{array}{l}\text { Data } \\
\text { source }\end{array}$ \\
\hline Regulating & Climate regulation & Climate & Inverse daily temperatures range & ${ }^{\circ} \mathrm{C}^{-1}$ & Sampled \\
\hline Regulating & Gas regulation & Gas & Carbon sequestration by plants & $\mathrm{C}_{2}$ eqTons/Ha & Database \\
\hline Regulating & Soil stability & Soil & Organic matter layer in top soil & $\mathrm{cm}^{2}$ & Sampled \\
\hline Regulating & Nutrient regulation & Nutrient & Total nitrogen in top soil & ppm & Sampled \\
\hline Supporting & Habitat quality & Habitat & Riparian quality index & Score & Sampled \\
\hline Provisioning & Raw materials & Raw_mat & Annual biomass increase & Tons/Ha & Database \\
\hline Provisioning & Food production & Food & Nutritive productivity & $\mathrm{Kcal} / \mathrm{Ha}$ & Database \\
\hline Cultural & Fishing & Fishing & Kilometric abundance index & $\mathrm{Km} / \mathrm{Km}$ & Database \\
\hline Cultural & Sports & Sports & Trails with a view over the area & $\mathrm{Ha}$ & Database \\
\hline Cultural & Recreation & Recreation & Areas for local amenity & Items & Sampled \\
\hline Cultural & Education & Education & $\begin{array}{l}\text { Notice boards with information about } \\
\text { the ecosystem }\end{array}$ & Items & Sampled \\
\hline Cultural & Social relationships & Assoc & $\begin{array}{l}\text { Nature user local associations (both } \\
\text { farmer unions and conservationists) }\end{array}$ & Number & Sampled \\
\hline
\end{tabular}

and downstream, based on the amount of water available for agricultural use. In the upper floodplain, the river is dry for most of the year and dry cereal crops are cultivated. The central floodplain, which is rich in water springs, is devoted to highly productive irrigated cereal crops and poplar groves. The downstream floodplain, separated from the central floodplain by a reservoir, is characterized by orchards, fruit groves, and abandoned agricultural lands. There are also two main natural areas in the watershed. One of them is located in the upper floodplain gorges and the other, just upstream from the reservoir, is a private natural park whose waterfalls attract thousands of tourists each year.

Fig. 1. Location of the study area in Spain (left). Piedra River watershed and municipalities traversed by the Piedra River (center). On the right, detail of the river floodplain spatial distribution showing some land-use types and sample points.

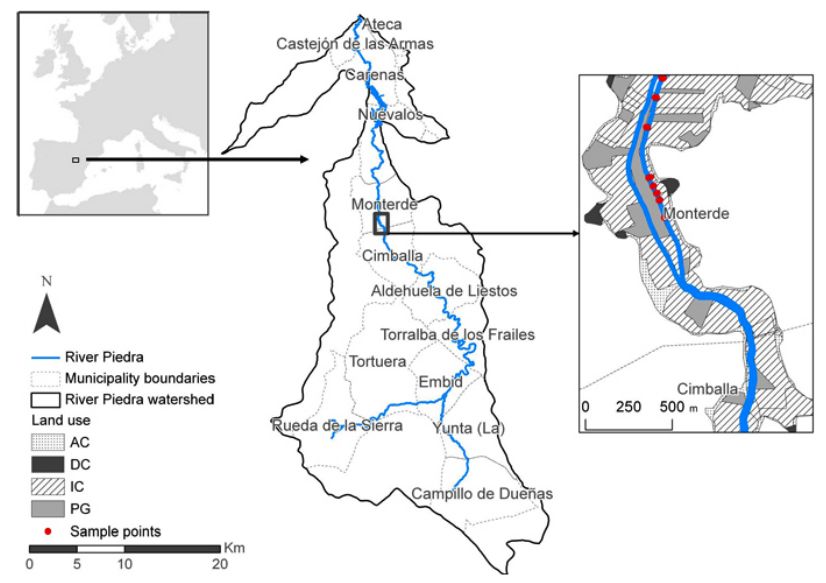

\section{Data gathering and analyses}

We selected 12 ES to measure based on their importance for the ecological functioning of a river floodplain (see Harrison et al. 2010) and our ability to assess them in the study area (Table 2). We estimated the provision of these ES in seven different landuse types common to the Piedra River floodplain (Table 3). We measured the area of each land-use type using the latest Spanish crop and land-use digital map (Ministerio de Medio Ambiente Y Medio Rural y Marino 2009) with ArcGIS 10 (ESRI 2012) and validated these measurements with field observations. We assessed ES at three spatial scales, i.e., patch, municipality, and landscape, in which municipality scale comprises the portion of each municipality within the river floodplain, ranging from 0.5 to $3.4 \mathrm{~km}^{2}$ in area and including several land-use types, and landscape scale refers to the entire floodplain of the Piedra River catchment.

To assess ES provision, we either estimated the ES indicators directly or obtained the values for ES indicators from public databases (Table 2, see Appendix 1 for details). For directly sampled ES, we surveyed three 0.5 ha patches in representative sites of each land-use type distributed throughout the river floodplain. Within each of these patches, three floodplain-wide transects perpendicular to the river channel were established 25 $\mathrm{m}$ apart. The appropriate indicators were measured at $1 \mathrm{~m}, 5 \mathrm{~m}$, and $15 \mathrm{~m}$ away from the river along each transect. These values were averaged to determine the overall mean provision of services in that land-use type at the patch scale. Data obtained from databases were available as average values per hectare by land-use type, except for the services of fishing areas and sports, which were available as mapped trails and their length was measured using GIS tools.

For regulating, supporting, and provisioning services, we first quantified ES provided within individual patches of unique land use, and used this data to estimate total provision at the municipality and landscape scales based on the total area of each land-use type at each of these scales. Thus, to scale from the patch 
Table 3. Main land uses identified in the Piedra River floodplain, abbreviations utilized in following tables and figures, proportion of each land-use type at each spatial scale, total extent they occupy, and percentage of the floodplain each one represents. Note that Water includes both the Piedra River and its reservoir of $5.60 \mathrm{~km}^{2}$ surface and Others refers to minor land uses representing less that $1 \%$ each one, e.g., vineyards, almond trees.

\begin{tabular}{|c|c|c|c|c|c|c|}
\hline Main land uses & Abbrev. & $\begin{array}{c}\text { Proportion at } \\
\text { patch scale }\end{array}$ & $\begin{array}{c}\text { Proportion at } \\
\text { municipality scale }\end{array}$ & $\begin{array}{c}\text { Proportion at } \\
\text { landscape scale }\end{array}$ & $\begin{array}{c}\text { Total extent } \\
\left(\mathrm{km}^{2}\right)\end{array}$ & $\begin{array}{c}\text { Percentage in the } \\
\text { landscape }\end{array}$ \\
\hline Abandoned crops & $\mathrm{AC}$ & 0.28 & 0.01 & 0.02 & 0.28 & 1.45 \\
\hline Dry cereal crops & DC & 0.16 & 0.36 & 0.38 & 5.38 & 27.82 \\
\hline Fruit groves & FG & 0.06 & 0.08 & 0.08 & 1.12 & 5.81 \\
\hline Irrigated crops & $\mathrm{IC}$ & 0.07 & 0.19 & 0.13 & 1.8 & 9.30 \\
\hline Poplar groves & PG & 0.09 & 0.04 & 0.05 & 0.71 & 3.66 \\
\hline Riparian forests & $\mathrm{RF}$ & 0.20 & 0.05 & 0.04 & 0.51 & 2.64 \\
\hline Urban areas & UA & 0.06 & 0.06 & 0.09 & 1.23 & 6.34 \\
\hline Others & & 0.08 & 0.22 & 0.22 & 1.2 & 6.23 \\
\hline Water & & & & & 7.1 & 36.74 \\
\hline Total study area & & & & & 19.33 & 100 \\
\hline
\end{tabular}

to municipality, ES values at the patch scale were multiplied by the extent of each land-use type within each municipality. Average values of each ES by land-use type across all municipalities were used at the municipality scale. To scale up to the landscape, ES values at the patch scale were multiplied by the total extent of each land-use type in the whole river floodplain.

Cultural services were measured at the municipality scale, rather than the patch, and therefore cultural ES were downscaled from the municipality scale to the patch scale by dividing the ES value per municipality by the extent of each land use within each municipality, and averaging. To scale up cultural ES to the landscape, ES values at the municipality scale were aggregated by land-use type (further information about spatial scale adaptation is provided in Appendix 1).

To determine the key spatial scale to manage land-use planning based on the provision of ES, we compared the amount of each service provided relative to other services across the patch, municipality, and landscape scales. To do this, we estimated the proportion of each land-use type at each spatial scale and multiplied it by the ES provision values of each land-use type at its corresponding scale (Table 3). We expected this scaling technique to be useful to discriminate the provision of ES by a range of land-use types at different spatial scales because landuse extension is independent from municipalities and the landscape. Finally, to simulate scenarios in which a single land use occupied the entire floodplain landscape, we multiplied the ES supply per hectare of each land-use type by the extent of the floodplain landscape.

We plotted these results using the graphics package (Murrell 2005) of the statistical software R (R Development Core Team 2012). To detect significant differences in the provision of ES among the studied land uses and spatial scales, we performed generalized linear mixed models (GLMM) fitted with the Poisson family distribution using the 'Ime4' R package (Bates et al. 2012). For this, we estimated each ES (response variable) as a function of the interaction between land-use type and spatial scale (categorical variables). Models were validated by checking the model residual plots (Zuur et al. 2009). We performed multiple comparison tests ('multcomp' R package; Hothorn et al. 2008) and figures plots ('effects' R package; Fox 2003) to determine significant differences among the means. Finally, to test the significance of ES interactions and their directions, i.e., positive or negative, Spearman correlation from the 'AED' R package (Zuur et al. 2009) was applied. Interactions were considered significant positives, but not necessarily synergies, when $\mathrm{r}^{2}>0.5$ and significant negatives, and thus, trade-offs, when $\mathrm{r}^{2}<-0.5$. We also considered the interactions among ES by each land-use type separately using the same techniques.

\section{RESULTS}

Changes in the supply of ecosystem services across land-use types and spatial scales

Each land-use type in our study provided unique mixtures and quantities of ES, but some land uses did not provide some ES, for example, urban areas did not supply nutrient regulation. We also noticed that the importance of each land-use type in supplying ES varied across the spatial scales studied (Table 4; see also Appendix 2, Fig. S1). For instance, at the patch scale, riparian forest supplied more soil stability, nutrient regulation, habitat quality, sports, recreation, and education than any other land-use type. Similarly, fruit groves supplied more climate and gas regulation and raw materials. However, at the municipality and landscape scales, the key service suppliers changed, primarily because of the amount of land in each land-use type. So, for example, dry cereal cropland supplied the most climate regulation, soil stability, nutrient regulation, habitat quality, food production, and social relationships across the whole landscape, whereas fruit groves were the main supplier of gas regulation. Riparian forest also supplied the most sports, education, and recreation at the municipality and landscape scales.

Across all three spatial scales, three land uses consistently supplied ES in larger amounts than other land uses. They were riparian forests, i.e., ES provided largely in riparian forests were sports, 
Table 4. Ecosystem services delivered by different land uses at three spatial scales. i.e., patch, municipality, and landscape. (Abbreviations: $\mathrm{AC}=$ abandoned crops; $\mathrm{DC}=$ dry cereal crops; $\mathrm{FG}=$ fruit groves; $\mathrm{IC}=$ irrigated cereal crops; $\mathrm{PG}=$ poplar groves; $\mathrm{RF}=$ riparian forest; UA = urban areas).

\begin{tabular}{|c|c|c|c|c|c|c|c|c|c|c|c|c|}
\hline $\begin{array}{r}\text { Land } \\
\text { use }\end{array}$ & $\begin{array}{r}\text { Climate } \\
\text { regulation } \\
{ }^{\circ} \mathrm{C}^{-1}\end{array}$ & $\begin{array}{r}\text { Gas } \\
\text { regulation } \\
\mathrm{C}_{2} \text { eqTons/ } \\
\mathrm{Ha}\end{array}$ & $\begin{array}{r}\text { Soil } \\
\text { stability } \\
\mathrm{Cm}\end{array}$ & $\begin{array}{r}\text { Nutrient } \\
\text { regulation } \\
\text { Ppm }\end{array}$ & $\begin{array}{r}\text { Habitat } \\
\text { quality } \\
\text { Score }\end{array}$ & $\begin{array}{r}\text { Raw } \\
\text { materials } \\
\text { Tons/Ha }\end{array}$ & $\begin{array}{r}\text { Food } \\
\text { production } \\
\text { Kcal/Ha }\end{array}$ & Fishing & Sports & Recreation & Education & $\begin{array}{r}\text { Social } \\
\text { relationships } \\
\text { Number }\end{array}$ \\
\hline \multicolumn{13}{|l|}{ Patch } \\
\hline $\mathrm{AC}$ & 0.05 & 2.26 & 1.08 & 0.24 & 47.60 & 4.15 & 0 & 19.45 & 1.47 & 0.00 & 0.00 & 0.12 \\
\hline $\mathrm{DC}$ & 0.05 & 0.00 & 0.31 & 0.22 & 46.25 & 2.85 & 9989680 & 0.78 & 4.87 & 0.00 & 0.00 & 1.15 \\
\hline $\mathrm{FG}$ & 0.06 & 159.36 & 0.51 & 0.20 & 37.94 & 91.79 & 4503021 & 0.02 & 0.18 & 0.02 & 0.00 & 0.97 \\
\hline $\mathrm{IC}$ & 0.05 & 0.00 & 0.47 & 0.13 & 38.35 & 42.39 & 23645073 & 39.10 & 3.50 & 0.00 & 0.00 & 1.11 \\
\hline PG & 0.06 & 36.00 & 0.80 & 0.15 & 40.67 & 15.36 & 0 & 4.11 & 1.42 & 0.01 & 0.00 & 0.44 \\
\hline $\mathrm{RF}$ & 0.05 & 138.00 & 1.30 & 0.34 & 80.17 & 79.87 & 0 & 16.92 & 18.58 & 0.10 & 0.72 & 0.26 \\
\hline UA & 0.06 & 0.00 & 0.00 & 0.00 & 0.00 & 0.00 & 0 & 2.78 & 1.25 & 0.04 & 0.03 & 0.23 \\
\hline \multicolumn{13}{|c|}{ Municipality } \\
\hline $\mathrm{AC}$ & 0.38 & 15.87 & 7.56 & 1.66 & 334.27 & 29.12 & 0 & 3641.23 & 23.31 & 0.00 & 0.00 & 0.12 \\
\hline $\mathrm{DC}$ & 2.62 & 0.00 & 15.15 & 10.67 & 2260.74 & 139.09 & 488304640 & 593.16 & 22.60 & 0.00 & 0.00 & 1.15 \\
\hline $\mathrm{FG}$ & 1.21 & 2980.56 & 9.52 & 3.80 & 709.56 & 1716.75 & 84221510 & 13.41 & 0.39 & 0.33 & 0.00 & 0.97 \\
\hline IC & 1.18 & 0.00 & 10.49 & 2.96 & 861.87 & 952.77 & 531393467 & 5929.18 & 35.03 & 0.00 & 0.00 & 1.11 \\
\hline PG & 1.12 & 636.30 & 14.17 & 2.72 & 718.78 & 271.48 & 0 & 778.91 & 12.03 & 0.25 & 0.00 & 0.44 \\
\hline RF & 0.26 & 641.20 & 6.05 & 1.58 & 372.48 & 371.10 & 0 & 2566.12 & 46.44 & 0.45 & 3.36 & 0.26 \\
\hline UA & 0.67 & 0.00 & 0.00 & 0.00 & 0.00 & 0.00 & 0 & 420.86 & 2.62 & 0.45 & 0.36 & 0.23 \\
\hline \multicolumn{13}{|c|}{ Landscape } \\
\hline $\mathrm{AC}$ & 1.51 & 63.48 & 30.23 & 6.63 & 1337.08 & 116.49 & 0 & 14750.16 & 93.25 & 0.00 & 0.00 & 0.48 \\
\hline $\mathrm{DC}$ & 28.83 & 0.00 & 166.68 & 117.40 & 24868.16 & 1529.96 & 5371351039 & 593.16 & 248.60 & 0.00 & 0.00 & 12.64 \\
\hline $\mathrm{FG}$ & 7.28 & 17883.38 & 57.10 & 22.78 & 4257.35 & 10300.50 & 505329062 & 13.41 & 2.34 & 2.00 & 0.00 & 5.83 \\
\hline $\mathrm{IC}$ & 9.46 & 0.00 & 83.90 & 23.66 & 6894.95 & 7622.15 & 4251147735 & 29645.89 & 280.25 & 0.00 & 0.00 & 8.87 \\
\hline PG & 4.49 & 2545.20 & 56.67 & 10.86 & 2875.13 & 1085.92 & 0 & 3115.66 & 48.11 & 1.00 & 0.00 & 1.74 \\
\hline $\mathrm{RF}$ & 2.81 & 7053.18 & 66.60 & 17.37 & 4097.32 & 4082.13 & 0 & 12830.61 & 510.87 & 5.00 & 37.00 & 2.87 \\
\hline UA & 7.39 & 0.00 & 0.00 & 0.00 & 0.00 & 0.00 & 0 & 2104.29 & 28.86 & 5.00 & 4.00 & 2.57 \\
\hline
\end{tabular}

recreation, and education; fruit groves, i.e., gas regulation and raw materials; and dry cereal crops, i.e., social relationships. These land uses remain important across scales because they either supply an elevated level of service or cover a fairly extensive area. Further information about the supply of ES by each land use across spatial scales is depicted in Appendix 2 (Fig. S1).

In addition, the comparison among spatial scales about their relative provision of ES showed larger values for most ES at the patch scale, suggesting this is the key scale to manage ES in our study area. However, values of food production, fishing, and social relationships were larger at the municipality scale (Fig. 2; see also Appendix 2, Fig. S2, Tables S1-S3).

\section{Simulated scenarios}

Simulating scenarios in which a single land use occupied the entire floodplain landscape of the study area resulted in a large range of variation in ES provision. We observed that a landscape composed completely of the riparian forest would increase the widest variety of ES, namely, habitat quality, nutrient regulation, soil stability, and the majority of cultural services; a landscape specialized in fruit groves would have high levels of gas and climate regulation and raw materials production; a landscape covered by irrigated cereal crops would maximize food production; and a landscape dedicated to dry cereal crops would enhance social relationships (Fig. 3). Because of the differences in services provided across different land-use types, ultimately, preserving a mixture of land-use types is critical to providing a mixture of services in the landscape.
Fig. 2. Ecosystem services (ES) supply per hectare across spatial scales. Note that the majority of ES are delivered at patch scale, and only food production, fishing, and social relationships areas are supplied mainly at municipality scale. Pie size represents the relative value in relation to the reference pie chart (the maximum value of the data). Note that empty slices represent the minimum relative value to the contribution of that particular ES.

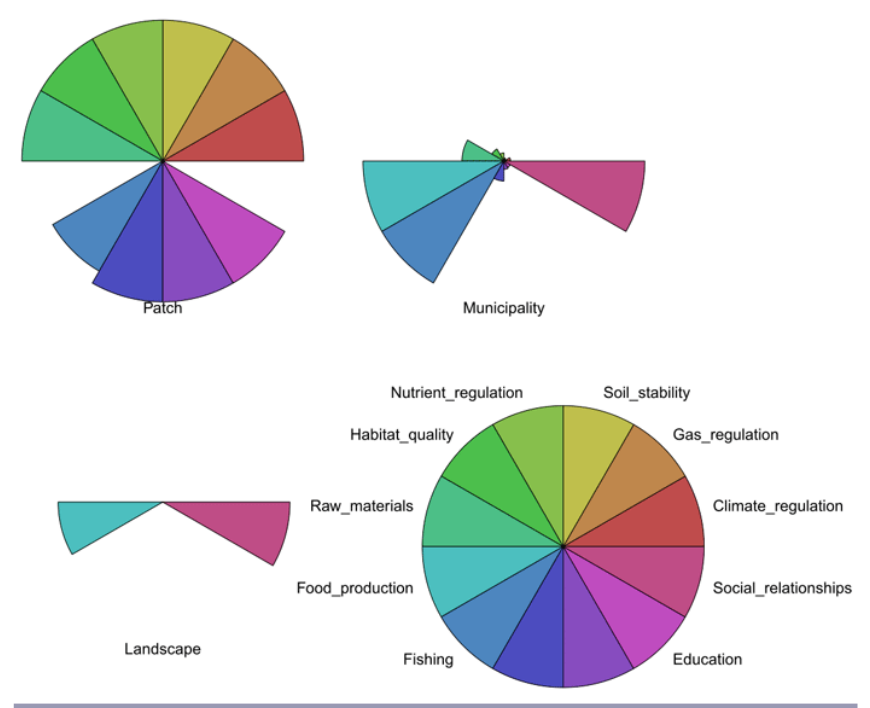


Fig. 3. Ecosystem services (ES) scenarios analysis in which we compare the maximum supply of ES by each land use assuming each one occupies the whole floodplain landscape. Pie size represents the relative value in relation to the reference pie chart (the maximum value of the data). Note that empty slices represent the minimum relative value to the contribution of that particular ES. (Abbreviations: $\mathrm{AC}=$ abandoned crops; $\mathrm{DC}=$ dry cereal crops; $\mathrm{FG}=$ fruit groves; $\mathrm{IC}=$ irrigated cereal crops; $\mathrm{PG}=$ poplar groves; $\mathrm{RF}=$ riparian forest; $\mathrm{UA}=$ urban areas).

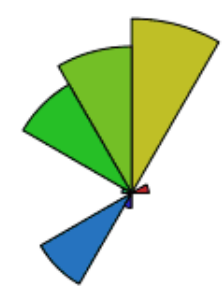

AC

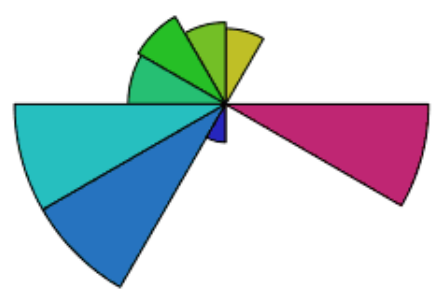

IC

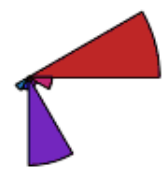

UA



DC

PG
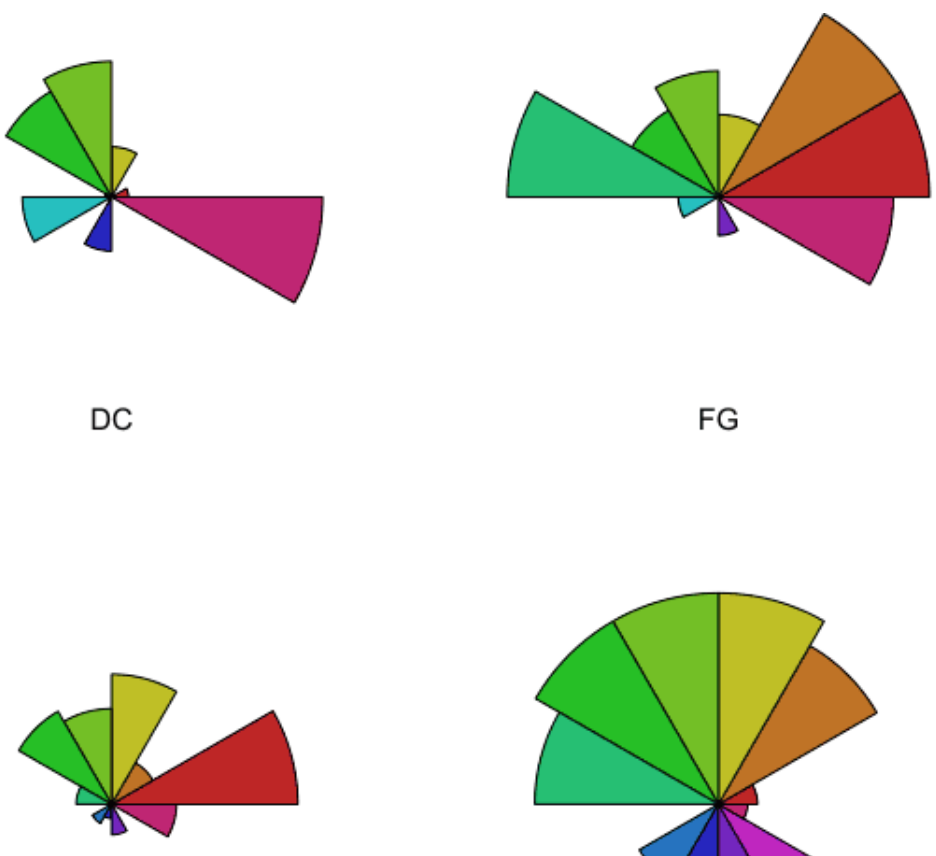

FG
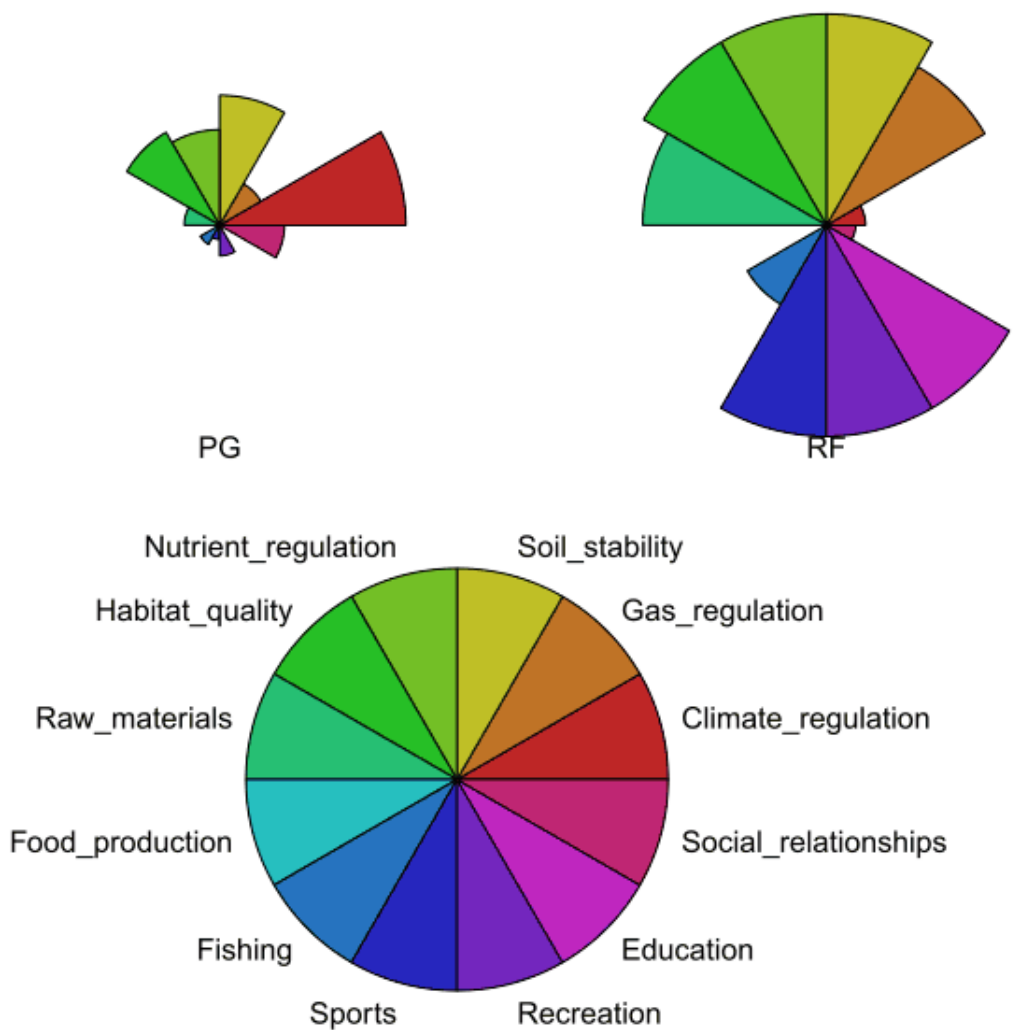
Table 5. Significant interactions $\left(r^{2}>0.5\right.$ or $\left.r^{2}<-0.5\right)$ found between ecosystem services (ES) at three different spatial scales. Note that positive interactions $(+)$ are common and negative interactions $(-)$ are rare. $($ Abbreviations: $\mathrm{p}=\mathrm{patch} ; \mathrm{m}=$ municipality; $1=$ landscape).

\begin{tabular}{|c|c|c|c|c|c|c|c|c|c|c|c|c|c|c|c|c|c|c|c|c|c|c|c|c|c|c|c|c|}
\hline & \multirow[b]{3}{*}{ Scale } & \multicolumn{27}{|c|}{ ES } \\
\hline & & \multicolumn{2}{|c|}{ Gas } & \multicolumn{3}{|c|}{ Soil } & \multicolumn{3}{|c|}{ Nutrient } & \multicolumn{3}{|c|}{ Habitat } & \multicolumn{2}{|c|}{ Raw_mat } & \multicolumn{3}{|c|}{ Food } & \multicolumn{2}{|c|}{ Fishing } & \multicolumn{2}{|c|}{ Sports } & \multicolumn{2}{|c|}{ Recreation } & \multicolumn{2}{|c|}{ Education } & \multicolumn{3}{|c|}{ Assoc } \\
\hline & & $\mathrm{p}$ & $\mathrm{m} 1$ & $\mathrm{p}$ & $\mathrm{m}$ & 1 & $\mathrm{p}$ & $\mathrm{m}$ & 1 & $\mathrm{p}$ & $\mathrm{m}$ & 1 & $\mathrm{p}$ & $\mathrm{m} 1$ & $\mathrm{p}$ & $\mathrm{m}$ & 1 & $\mathrm{p}$ & $\mathrm{m} 1$ & $\mathrm{p}$ & $\mathrm{m} 1$ & $\mathrm{p}$ & $\mathrm{m} 1$ & $\mathrm{p}$ & $\mathrm{m} 1$ & $\mathrm{p}$ & $\mathrm{m}$ & 1 \\
\hline \multicolumn{29}{|l|}{$\mathrm{ES}$} \\
\hline Climate & & + & & & + & & & + & & & + & & & & & + & + & - & & - & + & & & & & & & + \\
\hline Gas & & & & + & & & & & & & & & & + & & & & & + & & + & & + & & + & & & \\
\hline Soil & & & & & & & + & + & + & + & + & + & & + & & + & + & & & & + & & + & & + & & & + \\
\hline Nutrient & & & & & & & & & & + & + & + & & + & & + & + & & & & & & & & & & & + \\
\hline Habitat & & & & & & & & & & & & & & & & & + & & & + & & & & & & & & + \\
\hline Raw_mat & & & & & & & & & & & & & & & & & & & + & & + & & + & & + & & & \\
\hline Food & & & & & & & & & & & & & & & & & & & & & & & & & & + & & + \\
\hline Fishing & & & & & & & & & & & & & & & & & & & & + & + & & + & & + & & & \\
\hline Sports & & & & & & & & & & & & & & & & & & & & & & & + & & + & & & \\
\hline Recreation & & & & & & & & & & & & & & & & & & & & & & & & + & $+\quad+$ & & & \\
\hline Education & & & & & & & & & & & & & & & & & & & & & & & & & & & & \\
\hline
\end{tabular}

\section{Ecosystem services interactions: trade-offs and synergies across spatial scales and land-use types}

Relationships between ES varied across spatial scales. That is, some interactions, as measured by correlation, between ES were significant only at a single scale whereas others were significant at multiple spatial scales. Across scales, $21 \%$ of ES interactions varied in significance and $19 \%$ reversed from positive to negative or vice versa. The significant interactions between ES were $96 \%$ positive and just $4 \%$ negative (Table 5 ). However, only four of the significant positive interactions were consistent across all three spatial scales: the synergies among soil stability, nutrient regulation and habitat quality, and the synergy between recreation and education. Significant negative interactions were only observed between climate regulation and two other services, fishing and sports, at the patch scale. Finally, we found the largest number of significant positive interactions between ES at the scale of the municipality, especially between cultural and provisioning services.

Including the land-use type as a factor in ES interactions revealed that the only significant correlations were between cultural services, and they were all positive. Surprisingly, urban areas were the only land use in which all cultural services correlated among them. In riparian forests, fishing, recreation, education, and social relationships were also correlated. Finally, fishing and sports were correlated in all land uses except in riparian forest and abandoned crops (Table 6).

\section{DISCUSSION}

The results of our study support regional-level studies in finding that the supply of ES varies significantly among land-use types and across spatial scales. The variation in the ES supply derived from land-use change has been assessed over time regionally (Zhao et al. 2004, Helian et al. 2011, Carreño et al. 2012), but few works have compared the supply of multiple ES across multiple land-use types (but see Metzger et al. 2006), and even fewer have done so at a local scale. Our work also supports previous work illustrating that the scale of analysis can alter our understanding of ES provision (Chan et al. 2006, Hein et al 2006), because the cover of land-use types can change the types and quantities of ES provided at different scales. Ecosystem services (ES) that are prominent in a small-scale analysis may be insignificant at a larger spatial scale if the land-use type responsible for their provision is scarce. For example, in our study, habitat provision in riparian forests was very important at the patch scale, but its relevance was almost negligible at the landscape scale because of the small area riparian forests occupy in the floodplain. Likewise, climate regulation by a particular land use may seem unimportant at the patch scale, but become highly relevant when scaled up to the landscape scale because of a large area covered by that land use. Thus, the extent of any single land use at each spatial scale conditions the amount of service provided. Similarly for ES interactions, the spatial scale conditioned the scope of interactions. In our study area, only four interactions between ES remained consistent across spatial scales, highlighting the stability of some interactions. However, the majority of ES interactions changed across scales, indicating that there is no single relevant scale for analyzing ES interactions.

Although Raudsepp-Hearne et al. (2010) suggested that municipalities are a good scale at which to analyze ES interactions, in our multiscale study most ES interactions changed across spatial scales either in significance or in direction (positive vs. negative). This diversity of findings suggests that scientists and decision makers should be aware of the spatial scales at which ES are measured and managed (Daily 2000, Carpenter et al. 2005, de Groot et al. 2010). Although as many ES and interactions as possible should be analyzed for ES and trade-offs assessments, considering at least two spatial scales is key for decision making to assure that repercussions of management actions will stay consistent and will not reverse their effects once upscaled or downscaled. Better still, management actions should be adapted to each specific spatial scale (Aviron et al. 2009). For instance, we encountered difficulties in measuring cultural ES at the patch scale because the information about these services is typically available at the municipality scale. Thus, data had to be downscaled, causing a potential loss of ecologically meaningful data. Moreover, given that many cultural services are influenced by municipal regulations, e.g., access to paths, recreational and fishing areas, establishment of educative panels, etc., it is advisable to measure and manage them at the municipality scale. Trying to 
Table 6. Interactions between ecosystem services (ES) across land uses. Note that only significant interactions are shown. All of them were positive, and they were only found among cultural services. (Abbreviations: $\mathrm{AC}=$ abandoned crops; $\mathrm{DC}=\mathrm{dry}$ cereal crops; FG = fruit groves; $\mathrm{IC}=$ irrigated cereal crops; $\mathrm{PG}=$ poplar groves; $\mathrm{RF}=$ riparian forest; $\mathrm{UA}=$ urban areas).

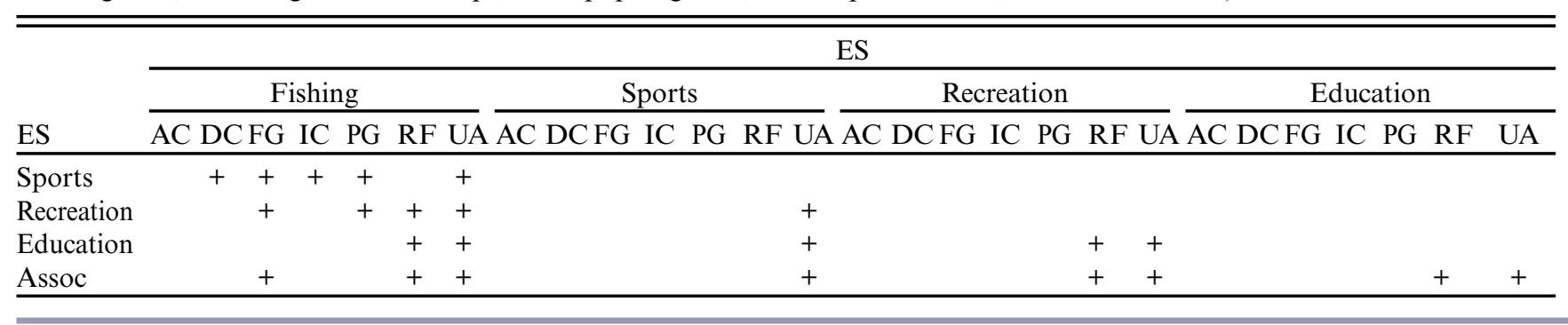

manage such services at a large scale, e.g., landscape, may lead to disagreement among government bodies. However, ES such as provisioning services are more amenable to management at the landscape scale despite information being typically available at both patch (per hectare values) and municipal or regional scales, because they greatly influence the landscape features in agroecosystems, and thus, the provision of services at the landscape scale. Therefore, understanding which services respond better to each particular spatial scale is useful for ES management. Matching the appropriate scale to both ES and trade-off analyses is important when payment schemes to protect ES or to encourage sustainable agriculture are to be implemented. Studies carried out in this respect were not able to assure that schemes to enhance ES in agricultural landscapes had the same positive effects locally as regionally or at the national scale (Kleijn et al. 2006). Similarly, field-scale actions did not have the same effects locally as at the landscape scale (Concepción et al. 2012). As we have shown, they argued that this was related to the extent of land-use types under these schemes. This is especially critical when consequences of land-use policies affect millions of people (Carreño et al. 2012), such as the Common Agricultural Policy in the European Union, which incentivized agricultural intensification but has also led to a decrease in biodiversity in agricultural landscapes (Tilman et al. 2002).

We quantified the existence of trade-offs in the supply of ES, as has been posited by many authors (Rodríguez et al. 2006, Nelson et al. 2009, Laterra et al. 2012). The Millennium Ecosystem Assessment (2005) classified ES trade-offs according to their temporal and spatial scales and also depending on their reversibility and the service targeted. Although it is widely recognized that trade-offs arise because of management decisions, which derive from societal needs, values, and preferences, there is little research involving societal values as a potential source of trade-offs (but see Martín-López et al. 2012). We have incorporated societal values as a likely cause of trade-offs between ES. Therefore, we classified ES interactions according to whether they can be driven by biophysical, i.e., ecological, factors or by societal values. In the first case, trade-offs are caused by biophysical interactions between ES and thus are consistent across all land uses (Table 7, example 1) or depend on the landuse type (Table 7, examples 2-4; see also Fig. 2, Table 4). Other trade-offs are caused by management decisions and are thus ultimately derived from societal values (Table 7, example 5).

We expect this classification would be applicable to other ecosystems for trade-offs analysis. Knowledge about the driving forces that provoke trade-offs can improve management for multiple ES. Biophysical trade-offs can often be reduced through specific biophysical management plans within a land-use type. For example, adequate pruning makes raw material production compatible with food production in fruit groves (Table 7, example 1) or with habitat quality in riparian forests (Table 7, example 3). Note that our results exposed the raw material production of fruit groves as a potential value, i.e., neglecting their use as fruit production. Moreover, when simultaneous gain is difficult to achieve, biophysical trade-offs can still be managed for suboptimal but compatible valuable gains (Chan et al. 2006, Trabucchi et al. 2013). Social trade-offs might be managed by considering the mix of land-use types. For example, as shown in Tables 5 and 6, most cultural services can be supplied concurrently with other ES (see also Martín-López et al. 2012).

Because of the high degree of synergies that involve cultural services, the possibility for enhancing the supply of a bundle of ES through promotion of cultural services exists in many municipalities. In our study area and probably in other river floodplains used for agricultural purposes, reopening public paths between the river and the field crops would enhance the supply of a bundle of cultural services yet causing minimal reductions in crop yield. Although synergies are more difficult to identify because significant positive correlations do not always mean that provision of one ES empowers supply of another (Table 7, examples 6-7), exploring in detail which ES or land uses correlate positively or present synergies improves the likelihood that we can enhance the total supply of ES in a targeted area. For example, promoting educational services together with recreational sites will increase the likely use of both services, enhancing the delivery of benefits to society.

Agroecosystems cover a large portion of the terrestrial surface of the Earth. As such, we cannot afford to manage them only for provisioning services because their management will condition the ES provision of the whole system. Rather, they should be managed to deliver multiple ES (Bennett and Balvanera 2006, Harrison et al. 2010), enhancing especially the provision of services of those land uses covering the larger extents of the agroecosystem. To achieve this goal, research on ES compatible with agroecosystems is crucial to improve our understanding of land-use interactions (Trabucchi et al. 2012). A more comprehensive study would likely be required to set the management policies in the area. However, we can already suggest that for the Piedra River, and similar floodplain agroecosystems, a mosaic of habitats comprising productive crops, poplar groves, 
Table 7. Summary of ecosystem services (ES) interactions at patch scale according to our findings.

\begin{tabular}{|c|c|c|c|c|}
\hline Case & Interaction & Origin & $\begin{array}{l}\text { Consistent across } \\
\text { land uses }\end{array}$ & Example \\
\hline $\begin{array}{l}\text { ES } 1 \text { cannot be supplied at the } \\
\text { same time as ES } 2 \text { in any of } \\
\text { the land uses. }\end{array}$ & Trade-off & $\begin{array}{l}\text { Biophysical, } \\
\text { ecological } \\
\text { interactions }\end{array}$ & Yes & $\begin{array}{l}\text { (1) Raw materials and food production } \\
\text { cannot be supplied at the same time. }\end{array}$ \\
\hline $\begin{array}{l}\text { ES } 1 \text { is always supplied by } \\
\text { land use } a \text { but ES } 2 \text { is never } \\
\text { supplied by land use } a \text {. }\end{array}$ & Trade-off & $\begin{array}{l}\text { Biophysical, } \\
\text { ecological } \\
\text { interactions }\end{array}$ & No & $\begin{array}{l}\text { (2) Urban areas always supply recreation } \\
\text { but never soil stability. }\end{array}$ \\
\hline $\begin{array}{l}\text { ES } 1 \text { and ES } 2 \text { can be supplied } \\
\text { at the same time at land use } a \text {, } \\
\text { but never together at land use } \\
b \text {. }\end{array}$ & Trade-off & $\begin{array}{l}\text { Biophysical, } \\
\text { ecological } \\
\text { interactions }\end{array}$ & No & $\begin{array}{l}\text { (3) Raw materials and habitat quality can } \\
\text { be supplied at the same time in riparian } \\
\text { forests but never together at poplar groves. }\end{array}$ \\
\hline $\begin{array}{l}\text { At land use } a, \text { ES1 and ES2 } \\
\text { have high values but at land } \\
\text { use } b \text { ES1 have same high } \\
\text { values and ES } 2 \text { have lower } \\
\text { values. }\end{array}$ & Trade-off & $\begin{array}{l}\text { Biophysical, } \\
\text { ecological } \\
\text { interactions }\end{array}$ & No & $\begin{array}{l}\text { (4) Raw materials and habitat quality have } \\
\text { high values at riparian forests; at fruit } \\
\text { groves raw materials still have high values } \\
\text { but habitat quality is very low. }\end{array}$ \\
\hline $\begin{array}{l}\text { ES } 1 \text { and ES } 2 \text { can be supplied } \\
\text { at the same time at land use } a \\
\text { and land use } b \text {, but only } \\
\text { sometimes appear together. }\end{array}$ & Trade-off & $\begin{array}{l}\text { Management } \\
\text { option, societal } \\
\text { decisions }\end{array}$ & Yes & $\begin{array}{l}\text { (5) Food provision and fishing areas can be } \\
\text { supplied at the same time at irrigated cereal } \\
\text { crops and riparian forest, but only } \\
\text { sometimes appear together. }\end{array}$ \\
\hline $\begin{array}{l}\text { ES } 1 \text { and ES } 2 \text { have lower } \\
\text { values at land use } a \text { when they } \\
\text { are alone than when they } \\
\text { appear together. }\end{array}$ & Synergy & $\begin{array}{l}\text { Biophysical, } \\
\text { ecological } \\
\text { interactions }\end{array}$ & Yes & $\begin{array}{l}\text { (6) Education and recreation have lower } \\
\text { users when they are supplied alone in a } \\
\text { location than when they are together. }\end{array}$ \\
\hline $\begin{array}{l}\text { ES } 1 \text { and ES } 2 \text { have medium } \\
\text { values at land uses } a \text { and } b \text { but } \\
\text { have always higher values at } \\
\text { land use } c \text {. }\end{array}$ & Synergy & $\begin{array}{l}\text { Biophysical, } \\
\text { ecological } \\
\text { interactions }\end{array}$ & No & $\begin{array}{l}\text { (7) Habitat quality and nutrient regulation } \\
\text { have medium values at dry cereal crops and } \\
\text { urban areas but have always higher values } \\
\text { at riparian forests. }\end{array}$ \\
\hline
\end{tabular}

fruit groves, and restored riparian habitats would increase the supply of ES and the resilience of the floodplain ecosystem, minimizing trade-offs and creating synergies for cultural services, which could ultimately foster rural agritourism, preserve local crops and livestock varieties, promote local products, create jobs, and eventually prevent village depopulation.

\section{CONCLUSION}

Each land-use type in the Piedra River floodplain provides ES in unique quantities. Thus, preserving a mixture of land-use types is critical to providing a mixture of services. The amount of each ES supplied in a given area depends on both the per hectare provision of service in a given type of land use and the total area of each land use. The relative importance of each land-use type in supplying ES and the significant interactions among ES change depending on the spatial scale at which measurements and analysis are done. Thus, it is critical to pay careful attention to the scale of analysis considered and its impact on the conclusions. Finally, societal values, as drivers of management decisions, should be studied along with biophysical factors because they likely cause trade-offs between ES and should be considered in management plans. Uncovering the driving forces that provoke trade-offs and exploring which ES or land uses present synergies, such as those shown between cultural services in many municipalities, will enhance land managers' ability to manage ES bundles.
Responses to this article can be read online at: http://www.ecologyandsociety.org/issues/responses. $\mathrm{php} / 6249$

\section{Acknowledgments:}

We are grateful to our technicians and students for helping us with field and lab work: A. Barcos, A. Massip, A. Mellado, B. Albero, C. Pastor, E. Lahoz, F. A. Araujo, L. Revuelto, M. Maestro, M. García, P. Errea, P. Sánchez, R. Sorando, and V. Lafuente. Thanks also to $A$. de Frutos for informatics and statistics help, to $M$. Zirger for English revision of the manuscript, and to A. de Frutos, $C$. Ziter and two anonymous reviewers for valuable comments on an earlier version of the manuscript. M. F. L. was granted by CSIC (Spanish National Research Council) under the JAE-predoc program, cofinanced by the European Social Fund. Funding for E. M. B. came from an NSERC Discovery grant.

\section{LITERATURE CITED}

Aviron, S., H. Nitsch, P. Jeanneret, S. Buholzer, H. Luka, L. Pfiffner, S. Pozzi, B. Schüpbach, T. Walter, and F. Herzog. 2009. Ecological cross compliance promotes farmland biodiversity in Switzerland. Frontiers in Ecology and the Environment 7 (5):247-252. http://dx.doi.org/10.1890/070197 
Barral, M. P., and O. N. Maceira. 2012. Land-use planning based on ecosystem service assessment: a case study in the southeast Pampas of Argentina. Agriculture, Ecosystems and Environment 154:34-43. http://dx.doi.org/10.1016/j.agee.2011.07.010

Bates, D., M. Maechler, and B. Bolker. 2012. lme4: linear mixedeffects models using S4 classes. R package version 0.999999-0. [online] URL: http://CRAN.R-project.org/package=lme4

Bennett, E. M., and P. Balvanera. 2007. The future of production systems in a globalized world. Frontiers in Ecology and the Environment 5:191-198. http://dx.doi.org/10.1890/1540-9295 (2007)5[191:TFOPSI]2.0.CO;2

Bennett, E. M., G. D. Peterson, and L. J. Gordon. 2009. Understanding relationships among multiple ecosystem services. Ecology Letters 12:1394-1404. http://dx.doi.org/10.1111/ j.1461-0248.2009.01387.x

Boletín Oficial de Aragón (BOA). 2012. ORDEN de 25 de enero de 2012, del Departamento de Agricultura, Ganadería y Medio Ambiente, por la que se aprueba el Plan General de Pesca de Aragón para el año 2012. Núm. 19.

Cabell, J. F., and M. Oelofse. 2012. An indicator framework for assessing agroecosystem resilience. Ecology and Society 17(1): 18. http://dx.doi.org/10.5751/ES-04666-170118

Carpenter, S. R., H. A. Mooney, J. Agard, D. Capistrano, R. S. DeFries, S. Díaz, T. Dietz, A. K. Duraiappah, A. Oteng-Yeboah, H. M. Pereira, C. Perrings, W. V. Reid, J. Sarukhan, R. J. Scholes, and A. Whyte. 2009. Science for managing ecosystem services: beyond the Millennium Ecosystem Assessment. Proceedings of the National Academy of Sciences 106:1305-1312. http://dx.doi. org/10.1073/pnas.0808772106

Carpenter, S. R., P. L. Pingali, E. M. Bennett, and M. B. Zurek, editors. 2005. Millennium ecosystem assessment: ecosystems and human well-being: scenarios. Volume 2. Findings of the Scenarios Working Group. Island, Washington, D.C., USA.

Carreño, L., F. C. Frank, and E. F. Viglizzo. 2012. Tradeoffs between economic and ecosystem services in Argentina during 50 years of land-use change. Agriculture, Ecosystems and Environment 154:68-77. http://dx.doi.org/10.1016/j.agee.2011.05.019

Centro de Investigación y Tecnología Agroalimentaria de Aragón/Agrifood Research and Technology Centre of Aragon (CITA). 2008. Estudio sobre la funcionalidad de la vegetación leñosa de Aragón como sumidero de $\mathrm{CO}_{2}$ : existencias y potencialidad (estimación cuantitativa y predicciones de fijación).

Centro de Investigación y Tecnología Agroalimentaria de Aragón, Zaragoza, Spain. [online] URL: http://www.aragon.es/ estaticos/GobiernoAragon/Departamentos/MedioAmbiente/

Areas/03 Cambio climatico/06 Proyectos actuaciones Emisiones GEI/ estudio.pdf

Chan, K. M. A., M. R. Shaw, D. R. Cameron, E. C. Underwood, and G. C. Daily. 2006. Conservation planning for ecosystem services. PLoS Biol 4:e379. http://dx.doi.org/10.1371/journal. pbio. 0040379

Chen, N., H. Li, and L. Wang. 2009. A GIS-based approach for mapping direct use value of ecosystem services at a county scale: management implications. Ecological Economics 68:2768-2776. http://dx.doi.org/10.1016/j.ecolecon.2008.12.001

Concepción, E. D., M. Díaz, D. Kleijn, A. Báldi, P. Batáry, Y. Clough, D. Gabriel, F. Herzog, A. Holzschuh, E. Knop, E. J. P. Marshall, T. Tscharntke, and J. Verhulst. 2012. Interactive effects of landscape context constrain the effectiveness of local agrienvironmental management. Journal of Applied Ecology 49:695-705. http://dx.doi.org/10.1111/j.1365-2664.2012.02131.x

Costanza, R., R. d'Arge, R. de Groot, S. Farber, M. Grasso, B. Hannon, K. Limburg, S. Naeem, R. V. O’Neill, J. Paruelo, R. G. Raskin, P. Sutton, and M. van den Belt. 1997. The value of the world's ecosystem services and natural capital. Nature 387:253-260. http://dx.doi.org/10.1038/387253a0

Daily, G. C. 2000. Management objectives for the protection of ecosystem services. Environmental Science and Policy 3:333-339. http://dx.doi.org/10.1016/S1462-9011(00)00102-7

DeFries, R. S., J. A. Foley, and G. P. Asner. 2004. Land-use choices: balancing human needs and ecosystem function. Frontiers in Ecology and the Environment 2:249-257. http://dx.doi. org/10.1890/1540-9295(2004)002[0249:LCBHNA]2.0.CO;2

de Groot, R. S., M. A. Wilson, and R. M. J. Boumans. 2002. A typology for the classification, description and valuation of ecosystem functions, goods and services. Ecological Economics 41:393-408. http://dx.doi.org/10.1016/S0921-8009(02)00089-7

de Groot, R. S., R. Alkemade, L. Braat, L. Hein, and L. Willemen. 2010. Challenges in integrating the concept of ecosystem services and values in landscape planning, management and decision making. Ecological Complexity 7(3):260-272. http://dx.doi. org/10.1016/j.ecocom.2009.10.006

Eigenbrod, F., P. R. Armsworth, B. J. Anderson, A. Heinemeyer, S. Gillings, D. B. Roy, C. D. Thomas, and K. J. Gaston. 2010. The impact of proxy-based methods on mapping the distribution of ecosystem services. Journal of Applied Ecology 47:377-385. http:// dx.doi.org/10.1111/j.1365-2664.2010.01777.x

Environmental Systems Resource Institute (ESRI). 2012. ArcGIS Desktop (10.0). Redlands, California, USA.

Felipe-Lucia, M. R. 2012. Social dimension of ecosystem services: the case of river Piedra's valley. Thesis. Universidad Pablo de Olavide, Sevilla, Spain.

Fox, J. 2003. Effect displays in R for generalised linear models. Journal of Statistical Software 8(15):1-27. [online] URL: http:// www.jstatsoft.org/v08/i15/

Goldstein, J. H., G. Caldarone, T. K. Duarte, D. Ennaanay, N. Hannahs, G. Mendoza, S. Polasky, S. Wolny, and G. C. Daily. 2012. Integrating ecosystem-service tradeoffs into land-use decisions. Proceedings of the National Academy of Sciences 109:7565-7570. http://dx.doi.org/10.1073/pnas.1201040109

González del Tánago M., D. García de Jalón, F. Lara, and R. Garilleti. 2006. Índice RQI para la valoración de las riberas fluviales en el contexto de la directiva marco del agua. Ingeniería Civil 143:97-108. [online] URL: http://www2.montes.upm.es/ Dptos/DptoIngForestal/Hidrobiolog $\%$ C3\%ADa/Publicaciones/ INDICE RQI.pdf 
Harrison P. A., M. Vandewalle, M. T. Sykes, P. M. Berry, R. Bugter, F. de Bello, C. K. Feld, U. Grandin, R. Harrington, J. R. Haslett, R. H. G. Jongman, G. W. Luck, P. M. da Silva, M. Moora, J. Settele, J. P. Sousa, and M. Zobel. 2010. Identifying and prioritizing services in European terrestrial and freshwater ecosystems. Biodiversity and Conservation 19:2791-2821. http:// dx.doi.org/10.1007/s10531-010-9789-x

Hein, L., K. van Koppen, R. S. de Groot, and E. C. van Ierland. 2006. Spatial scales, stakeholders and the valuation of ecosystem services. Ecological Economics 57:209-228. http://dx.doi. org/10.1016/j.ecolecon.2005.04.005

Helian, L., W. Shilong, J. Guanglei, and Z. Ling. 2011. Changes in land use and ecosystem service values in Jinan, China. Energy Procedia 5:1109-1115. http://dx.doi.org/10.1016/j.egypro.2011.03.195

Hothorn, T., F. Bretz, and P. Westfall. 2008. Simultaneous inference in general parametric models. Biometrical Journal 50 (3):346-363. http://dx.doi.org/10.1002/bimj.200810425

Hubbart, J. A. 2011. An inexpensive alternative solar radiation shield for ambient air temperature and relative humidity microsensors. Journal of Natural and Environmental Sciences 2:9-14. [online] URL: http://www.asciencejournal.net/asj/index.php/ NES/article/view/214/214

Hubbart, J. A., T. Link, C. Campbell, and D. Cobos. 2005. Evaluation of a low-cost temperature measurement system for environmental applications. Hydrological Processes 19:1517-1523. http://dx.doi.org/10.1002/hyp.5861

Instituto Aragonés de Estadística. 2011. Padron Municipal of Inhabitants 01/01/2011. Gobierno de Aragón, Zaragoza, Spain. [online] URL: http://www.aragon.es/DepartamentosOrganismosPublicos/ Organismos/InstitutoAragonesEstadistica/AreasTematicas/02 Demografia_Y_Poblacion/01_CifrasPoblacion_Y_Censos/01_Padron/ ci.01_Cifras_oficiales_poblacion.detalleDepartamento?channelSelected= cb5ca856c66de310VgnVCM2000002f551bacRCRD

Instituto Nacional de Estadística. 2008. Municipal surface. 01/01/2008. Instituto Nacional de Estadística, Madrid, Spain. [online] URL: http://www.ine.es

Kleijn, D., R. A. Baquero, Y. Clough, M. Díaz, J. De Esteban, F. Fernández, D. Gabriel, F. Herzog, A. Holzschuh, R. Jöhl, E. Knop, A. Kruess, E. J. P. Marshall, I. Steffan-Dewenter, T. Tscharntke, J. Verhulst, T. M. West, and J. L. Yela. 2006. Mixed biodiversity benefits of agri-environment schemes in five European countries. Ecology Letters 9:243-254. http://dx.doi. org/10.1111/j.1461-0248.2005.00869.X

Konarska, K. M., P. C. Sutton, and M. Castellon. 2002. Evaluating scale dependence of ecosystem service valuation: a comparison of NOAA-AVHRR and Landsat TM datasets. Ecological Economics 41: 491-507. http://dx.doi.org/10.1016/ S0921-8009(02)00096-4

Kreuter, U. P., H. G. Harris, M. D. Matlock, and R. E. Lacey. 2001. Change in ecosystem service values in the San Antonio area, Texas. Ecological Economics 39:333-346. http://dx.doi.org/10.1016/ $\underline{\text { S0921-8009(01)00250-6 }}$

Laterra, P., M. E. Orúe, and G. C. Booman. 2012. Spatial complexity and ecosystem services in rural landscapes.
Agriculture, Ecosystems and Environment 154:56-67. http://dx. doi.org/10.1016/j.agee.2011.05.013

Millennium Ecosystem Assessment (MEA). 2005. Millenium Ecosystem Assessment. Island, Washington, D.C., USA.

Ministerio de Medio Ambiente Y Medio Rural y Marino. 2009. Mapa de cultivos y aprovechamientos, actualización 2000-2009. Escala 1:50000. Ministerio de Medio Ambiente Y Medio Rural y Marino, Madrid, Spain.

Martín-López, B., I. Iniesta-Arandia, M. García-Llorente, I. Palomo, I. Casado-Arzuaga, D. G. Del Amo, E. GómezBaggethun, E. Oteros-Rozas, I. Palacios-Agundez, B. Willaarts, J. A. González, F. Santos-Martín, M. Onaindia, C. LópezSantiago, and C. Montes. 2012. Uncovering ecosystem service bundles through social preferences. PLoS ONE 7. http://dx.doi. org/10.1371/journal.pone.0038970

Metzger, M. J., M. D. A. Rounsevell, L. Acosta-Michlik, R. Leemans, and D. Schröter. 2006. The vulnerability of ecosystem services to land use change. Agriculture, Ecosystems and Environment 114:69-85. http://dx.doi.org/10.1016/j.agee.2005.11.025

Mitchell, M. G. E., E. M. Bennett, and A. Gonzalez. 2013. Linking landscape connectivity and ecosystem service provision: current knowledge and research gaps. Ecosystems 16:894-908. http://dx.doi.org/10.1007/s10021-013-9647-2

Montero G., R. Ruiz-Peinado, and M. Muñoz. 2005. Producción de biomasa y fijación de $\mathrm{CO}_{2}$ por los bosques españoles. Instituto Nacional de Investigación y Tecnología Agraria y Alimentaría (INIA), Madrid, Spain.

Moss, T., and J. Monstadt. 2008. Institutional dimensions of floodplain restoration in Europe: an introduction. Pages 3-15 in T. Moss and J. Monstadt, editors. Restoring floodplains in Europe. International Water Association (IWA), London, UK.

Murrell, P. 2005. R graphics. Chapman and Hall/CRC, Boca Raton, Florida, USA.

Nelson, E., G. Mendoza, J. Regetz, S. Polasky, H. Tallis, D. R. Cameron, K. M. A. Chan, G. C. Daily, J. Goldstein, P. M. Kareiva, E. Lonsdorf, R. Naidoo, T. H. Ricketts, and M. R. Shaw. 2009. Modeling multiple ecosystem services, biodiversity conservation, commodity production, and tradeoffs at landscape scales. Frontiers in Ecology and the Environment 7:4-11. http://dx.doi. org/10.1890/080023

Nicholson, E., G. M. Mace, P. R. Armsworth, G. Atkinson, S. Buckle, T. Clements, R. M. Ewers, J. E. Fa, T. A. Gardner, J. Gibbons, R. Grenyer, R. Metcalfe, S. Mourato, M. Muûls, D. Osborn, D. C. Reuman, C. Watson, and E. J. Milner-Gulland. 2009. Priority research areas for ecosystem services in a changing world. Journal of Applied Ecology 46:1139-1144. http://dx.doi. org/10.1111/j.1365-2664.2009.01716.x 
Pereira, H. M., B. Reyers, M. Watanabe, E. Bohensky, S. Foale, C. Palm, M. V. Espaldon, D. Armenteras, M. Tapia, A. Rincón, M. J. Lee, A. Patwardhan, and I. Gomes. 2005. Condition and trends of ecosystem services and biodiversity. Pages 171-203 in D. Capistrano, C. Samper, M. J. Lee, and C. Raudsepp-Hearne, editors. Millenium ecosystems assessment: ecosystems and human well-being: multiscale assessments. Volume 4. Findings of the Subglobal Assessments Working Group of the Millennium Ecosystem Assessment. Island, Washington, D.C., USA.

Pringle, R. M., D. F. Doak, A. K. Brody, R. Jocqué, and T. M. Palmer. 2010. Spatial pattern enhances ecosystem functioning in an African savanna. PLoS Biol 8(5). http://dx.doi.org/10.1371/ journal.pbio. 1000377

Power, A. G. 2010. Ecosystem services and agriculture: tradeoffs and synergies. Philosophical Transactions of the Royal Society: Biological Sciences 365:2959-2971. http://dx.doi.org/10.1098/ rstb.2010.0143

Quantum GIS Development Team. 2012. Quantum GIS Desktop (1.8.0). Open Source Geospatial Foundation Project, Beaverton, Oregon, USA. http://qgis.osgeo.org

R Development Core Team. 2012. R: a language and environment for statistical computing. R Foundation for Statistical Computing, Vienna, Austria. http://www.R-project.org/

Rathwell, K. J., and G. D. Peterson. 2012. Connecting social networks with ecosystem services for watershed governance: a social-ecological network perspective highlights the critical role of bridging organizations. Ecology and Society 17(2):24. http:// dx.doi.org/10.5751/ES-04810-170224

Raudsepp-Hearne, C., G. D. Peterson, and E. M. Bennett. 2010. Ecosystem service bundles for analyzing tradeoffs in diverse landscapes. Proceedings of the National Academy of Sciences 107:5242-5247. http://dx.doi.org/10.1073/pnas.0907284107

Rodríguez, J. P., T. D. Beard, Jr., J. R. B. Agard, E. Bennett, S. Cork, G. Cumming, D. Deane, A. P. Dobson, D. M. Lodge, M. Mutale, G. C. Nelson, G. D. Peterson, and T. Ribeiro. 2005. Interactions among ecosystem services. Pages 431-448 in S. R. Carpenter, P. L. Pingali, E. M. Bennett, and M. B. Zurek, editors. Ecosystems and human well-being: scenarios. Volume 2. Findings of the Scenarios Working Group. Island, Washington, D.C., USA. [online] URL: http://www.unep.org/maweb/documents/ document.336.aspx.pdf

Rodríguez, J. P., T. D. Beard, Jr., E. M. Bennett, G. S. Cumming, S. J. Cork, J. R. B. Agard, A. P. Dobson, and G. D. Peterson. 2006. Trade-offs across space, time, and ecosystem services. Ecology and Society 11(1): 28. [online] URL: http://www.ecologyandsociety. org/vol11/iss1/art28/

Rose, S. K., and D. Chapman. 2003. Timber harvest adjacency economies, hunting, species protection, and old growth value: seeking the dynamic optimum. Ecological Economics 44:325-344. http://dx.doi.org/10.1016/S0921-8009(02)00268-9

Scheitlin, K. N., and P. G. Dixon. 2010. Diurnal temperature range variability due to land cover and air mass types in the Southeast. Journal of Applied Meteorology and Climatology 49:879-888. http://dx.doi.org/10.1175/2009JAMC2322.1
Simoncini, R. 2009. Developing an integrated approach to enhance the delivering of environmental goods and services by agro-ecosystems. Regional Environmental Change 9:153-167. http://dx.doi.org/10.1007/s10113-008-0052-x

Swift, M. J., A.-M. N. Izac, and M. van Noordwijk. 2004. Biodiversity and ecosystem services in agricultural landscapes are we asking the right questions? Agriculture, Ecosystems and Environment 104:113-134. http://dx.doi.org/10.1016/j.agee.2004.01.013

Tallis, H., and S. Polasky. 2009. Mapping and valuing ecosystem services as an approach for conservation and natural-resource management. Annals of the New York Academy of Sciences 1162:265-283. http://dx.doi.org/10.1111/j.1749-6632.2009.04152. $\underline{x}$

Tianhong, L., L. Wenkai, and Q. Zhenghan. 2010. Variations in ecosystem service value in response to land use changes in Shenzhen. Ecological economics 69:1427-1435. http://dx.doi. org/10.1016/j.ecolecon.2008.05.018

Tilman, D., K. G. Cassman, P. A. Matson, R. Naylor, and S. Polasky. 2002. Agricultural sustainability and intensive production practices. Nature 418:671-677. http://dx.doi. org/10.1038/nature01014

Tockner K., and J. A. Stanford. 2002. Riverine flood plains: present state and future trends. Environmental Conservation 29 (3):308-330 http://dx.doi.org/10.1017/S037689290200022X

Trabucchi, M. 2012. La evaluación de los servicios de los ecosistemas como herramienta para planificar la restauración ecológica de cuencas hidrográficas. Dissertation. Universidad de Zaragoza, Zaragoza, Spain. [online] URL http://zaguan.unizar. es/record/9910/files/TESIS-2012-144.pdf

Trabucchi, M., F. A. Comín, and P. J. O'Farrell. 2013. Hierarchical priority setting for restoration in a watershed in NE Spain, based on assessments of soil erosion and ecosystem services. Regional Environmental Change. 13(4):911-926. http://dx.doi.org/10.1007/ s10113-012-0392-4

Trabucchi, M., P. Ntshotsho, P. O’Farrell, and F. A. Comín. 2012. Ecosystem service trends in basin-scale restoration initiatives: a review. Journal of Environmental Management 111:18-23. http:// dx.doi.org/10.1016/j.jenvman.2012.06.040

Viglizzo, E. F., and F. C. Frank. 2006. Land-use options for Del Plata Basin in South America: tradeoffs analysis based on ecosystem service provision. Ecological Economics 57:140-151. http://dx.doi.org/10.1016/j.ecolecon.2005.03.025

Zhang, W., T. H. Ricketts, C. Kremen, K. Carney, and S. M. Swinton. 2007. Ecosystem services and dis-services to agriculture. Ecological Economics 64:253-260. http://dx.doi.org/10.1016/j. ecolecon.2007.02.024

Zhao, B., U. Kreuter, B. Li, Z. Ma, J. Chen, and N. Nakagoshi. 2004. An ecosystem service value assessment of land-use change on Chongming Island, China. Land Use Policy 21:139-148. http:// dx.doi.org/10.1016/j.landusepol.2003.10.003

Zuur, A. F., E. N. Ieno, N. J. Walker, A. A. Saveliev, and G. M. Smith. 2009. Mixed effects models and extensions in ecology with $R$. Springer, Amsterdam, the Netherlands. http://dx.doi. org/10.1007/978-0-387-87458-6 
Erratum. This version of Appendix 1 replaces the one originally published. The change was made on 27 February 2014.

\section{APPENDIX 1}

\section{Detailed methods for ES sampling, indicators selected and scale adaptation.}

\section{Climate regulation}

Temperature samples were recorded every 60 minutes over a period of 8 months (February to September 2012) using data loggers (iButton). Three devices per plot were hung from trees located at regular distances along a river transect perpendicular to the river channel. Three replicate plots were sampled in representative sites of each selected land use type. Dry cereal crops and Fruit groves were not surveyed but surrogate values from Abandoned crops and Poplar groves were used respectively, due to their similar cover and structure. Means of daily temperatures range (DTR=maximum temperature of day $\mathrm{x}$ - minimum temperature of day $\mathrm{x}$ ) (Scheitlin and Dixon 2010) were used as an indicator. Average values by land use were calculated and used as ES values. Inverse values (1/DTR) were used to ease graphics comparisons; by doing so, higher indicator values mean higher supply of the ES (Hubbart et al. 2005; Hubbart 2011).

\section{Gas regulation}

Annual $\mathrm{CO}_{2}$ sequestration rates were obtained from a national database (Montero 2005, CITA 2008) which estimated the amounts of carbon stored by the above- and belowground biomass of different plant species. This database calculates the species annual growth and transforms it into carbon equivalent tons per hectare, considering that Carbon stored $=$ Biomass $\times$ 0.4735. Then carbon is transformed into $\mathrm{CO}_{2}$ using their stoichiometric coefficients. Grass species are not supposed to store any $\mathrm{CO}_{2}$, because they grow up, die and get decomposed annually, and thus their annual balance equals zero (CITA 2008).

\section{Soil Stability}

The organic matter on topsoil $(0-10 \mathrm{~cm})$ was differentiated visually and its depth recorded with a measuring tape. Leaf litter was excluded. Three samples were taken along a river transect perpendicular to the river channel and three transects replicates were taken in each plot. Three plot replicates were sampled by land use except for urban soils. Soils were first surveyed in September 2010 and replicated in July 2011 and 2012. 


\section{Nutrient regulation}

Soil samples $(0.5 \mathrm{~kg})$ were taken from the topsoil $(0-15 \mathrm{~cm})$. Three samples were taken along a river transect perpendicular to the river channel and three transects replicates were taken in each plot. Three plots replicates were sampled by land use except for urban soils. Soils were dried, sieved and milled prior to lab analyses. Total Nitrogen was measured using a macro elemental analyzer (Vario Macro Max CN) and results were expressed in concentration ( $\mathrm{ppm}$ ). Soils were first surveyed in September 2010 and replicated in July 2011 and July 2012.

\section{Habitat quality}

Habitat quality was evaluated using the Riparian Quality Index (González del Tánago et al. 2006). Three replicate plots per land use were sampled during the field campaigns between July 2010, July 2011 and July 2012.

\section{Raw materials}

Annual growth rates per plant species were obtained from a national database (Montero 2005, CITA 2008) which calculated the annual growth as tons of biomass tons per hectare, considering that Biomass $=$ Correction factor $\mathrm{x}$ timber diameter. Grass species are not supposed to accumulate any biomass annually, because they grow up, die and get decomposed, and thus the annual balance equals zero (CITA 2008). Other woody species and woody formations were calculated individually by plant species.

\section{Food production}

Yield values for the crops growing within the study area were obtained from national databases statistics (Instituto Nacional de Estadística, updated on 30 October 2012) expressed as kilograms per hectare and multiplied by the crop caloric value (kilocalories per 100 grams). The ES value is expressed as kilocalories per hectare.

\section{Fishing}

Available fishing stretches for recreational use at the river Piedra were obtained from the fishing regulatory policy of 2012 for the Autonomous Community of Aragon (BOA 2012) and drawn using GIS tools (ArcGIS 10.0, ESRI). Fishing available stretches were computed for both riversides. Stretches were converted into polylines, their perimeters calculated and summarized into stretches available or unavailable for fishing. Polylines 
were converted into polygons and intersected to the land use cover with a buffer of $10 \mathrm{~m}$ to add both the land use and municipality information of each stretch of the river. Then lengths were recalculated. Total length across river stretches of each land use type was used as an indicator at landscape scale. Average values by land use type across municipalities were used as an indicator at landscape scale. The length of the river across each land use type in relation to the total length of the river (i.e. including areas unavailable for recreational fishing) and in reference to a 1 hectare patch (a patch of 100 meters of side) was used as an indicator at patch scale (i.e. Fishing at land use $x=$ (Total length of land use $x$ / Total length of the river)*100).

\section{Sports}

Tracks of post-signed and user-designed paths were downloaded from both the local tourist office website and wikilocs (http://senderos.turismodearagon.com and www.wikiloc.com, respectively; date of reference: 12 October 2012) following Trabucchi et al. (2013b). Tracks around the study area were unified using GIS tools (QGIS, Quantum GIS Development Team), and overlapped to the study area viewshed. Then the viewshed of the shapefile obtained was calculated and intersected to the land use cover. Finally the extent of each land use that can be seen from the open-to-public used paths was calculated. Average values per hectare of each land use were used at patch scale. Values at municipality and landscape scale were obtained directly from the GIS attribute table in hectares.

\section{Recreation}

The number of areas for social amenity per land use and municipality were counted in situ in all the municipalities in August 2012. The average number of rest areas per hectare of land use was estimated as the total number of rest areas of each land use in the study area divided by the total number of hectares that each particular land use covers within the study area.

\section{Education}

The number of notice boards with information about the ecosystem of the study area was counted in situ per land use and municipality in August 2012. To calculate the average number of notice boards per hectare of land use, the total number of notice 
boards of each land use was divided by the total number of hectares that each particular land use occupies within the study area.

\section{Social relationships}

The number of local associations related to the use of nature (either for conservation or for agriculture) per municipality within the study area was counted in August 2012. Downscaling to patch scale was estimated as follows,

$$
\operatorname{Assoc}_{X}=\frac{\sum_{\bar{i}=1}^{n}\left(\frac{A_{\bar{i}}}{S_{\bar{i}}} * X_{\bar{i}}\right)}{n}
$$

where $A \operatorname{ssoc}_{X}$ is the average number of local associations related to the use of nature at land use $x ; A$ is the number of local associations at municipality $i$; $S$ are hectares of municipality $i$ within the study area; $X$ are hectares of land use $x$ within the study area at municipality $i$; and $n$ is the number of municipalities. 


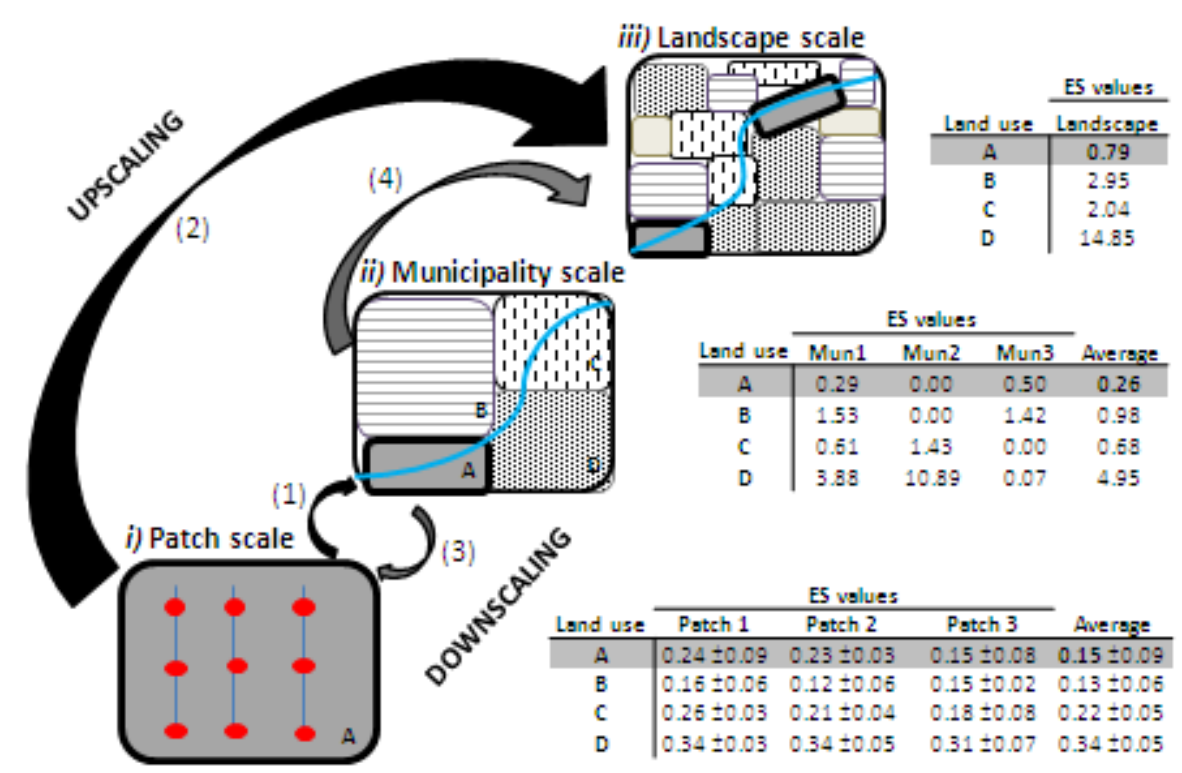

\begin{tabular}{c|cccc}
\multirow{2}{*}{ Land use } & \multicolumn{3}{c}{ Cover (ha) } & \multirow{2}{*}{ Total } \\
\cline { 2 - 4 } & Mun1 & Mun2 & Mun3 & \\
\hline A & 1.91 & 0.00 & 3.31 & 5.22 \\
B & 11.78 & 0.00 & 10.89 & 22.67 \\
C & 2.77 & 6.50 & 0.00 & 9.27 \\
D & 11.41 & 32.04 & 0.22 & 43.67
\end{tabular}

(1) $\begin{gathered}\text { (Average ES value at the patch } \\ x\end{gathered}$

n municipalities

Average ES value at the patch $x$ $\sum_{i=1}^{n}$ Cover of land use $A$ at municipality.

$\sum_{i=1}^{n}($ ES value at municipality: Cover of land use $A$ at municipality: $)$ n municipalities

(4) $\sum_{i=1}^{n} E S$ value at municipality:

Figure S1. ES scaling methods. The figure represents the scaling techniques used to obtain the values of ES provision by land use types (land use A, as an example) at three spatial scales (patch, municipality, and landscape). Assessment of regulating, supporting and provisioning services (black arrows, case 1) starts at the patch scale, and assessment of cultural services (greys arrows, case 2) starts at the municipality scale. In case 1 (e.g. Nutrient regulation), we sampled three patches per land use type (figure $i$ ) shows patch 1 of land use A) collecting 9 soil samples (red dots) per patch to analyze total nitrogen content as a proxy of the ES. We averaged values within each patch and across the three patches of land use A to obtain a unique value of the ES at the patch scale. To scale up to municipality (small black arrow, equation (1)), we used the average value of land use A at the patch scale (i.e. 0.15) and multiplied it by the cover of land use A at municipality 1 (Mun1, see Land cover table on the right; i.e. $0.15 \times 1.91=0.29$ ). We did the same with each municipality and averaged values to obtain a single value of ES provision by land use $\mathrm{A}$ at the municipality scale (i.e. 0.26). We started from the patch scale again to scale up to landscape (large black arrow, equation (2)). We used the average value of the ES for land use A and multiplied it by the total cover of land use A in the landscape (i.e. the sum of the cover of land use A across the three municipalities; $0.15 \times 5.22=0.78$ ). In case 2 (e.g. Education), we counted the number of educational sites within land use A in each municipality (figure ii) shows municipality 1 ). We scaled down to the patch (small grey arrow, equation (3)) dividing the ES value of each municipality by the cover of land use A in that municipality (e.g. for municipality $1,0.29 / 1.91=0.15$ ). We averaged these values across the three municipalities to obtain a single value of ES provision by land use A at the patch scale (i.e. $(0.15+0.00+0.15) / 3=0.1)$. To scale up to the landscape (large grey arrow, equation (4)), we summed the ES values at land use A across the three municipalities (i.e. $0.29+0.00+0.50=0.79)$. 


\section{APPENDIX 2}

\section{Detailed information about the supply of ES by each land use across spatial scales.}

Fig. S1. Relative contribution to the provision of ES by land use type at each spatial scale. Pie size represents the relative value in relation to the reference pie chart (the maximum value of the data). Note that empty slices represent the minimum relative value to the contribution of that particular ES. (Abbreviations: $\mathrm{AC}=$ abandoned crops; $\mathrm{DC}=$ dry cereal crops; $\mathrm{FG}=$ fruit groves; $\mathrm{IC}=$ irrigated cereal crops; $\mathrm{PG}=$ poplar groves; $\mathrm{RF}=$ riparian forest; $\mathrm{UA}=$ urban areas).

\section{Patch scale}



$\mathrm{AC}$

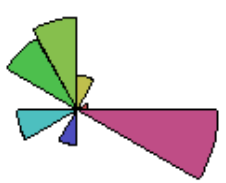

DC

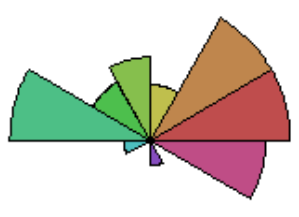

FG

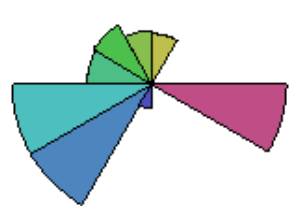

IC



PG


UA

\section{Municipality scale}



$\mathrm{AC}$

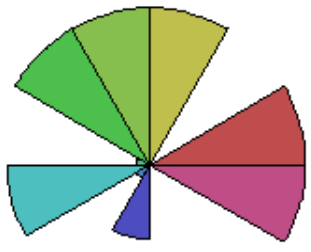

DC

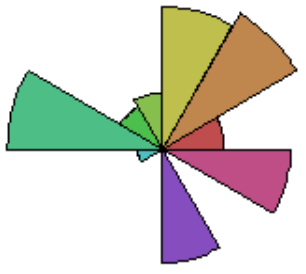

$F G$

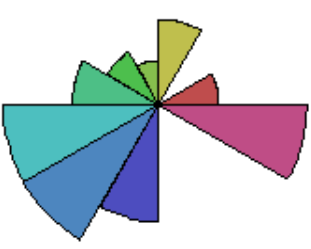

IC
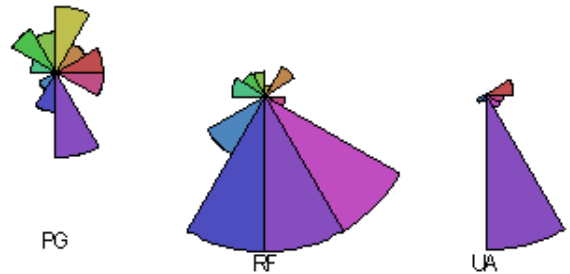

\section{Landscape scale}

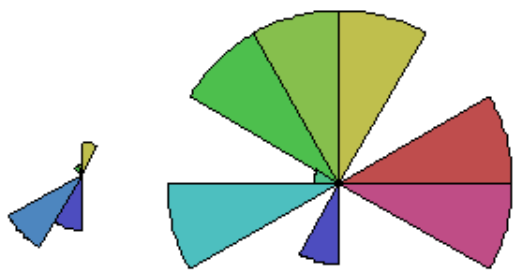

AC

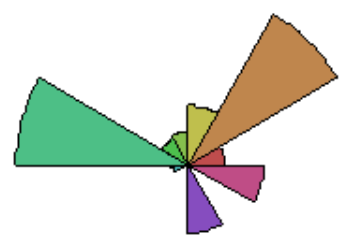

FG

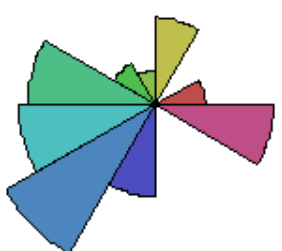

IC

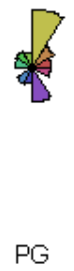

PG
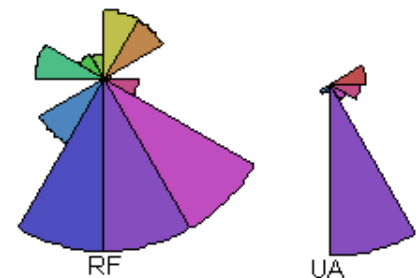

\section{Reference}

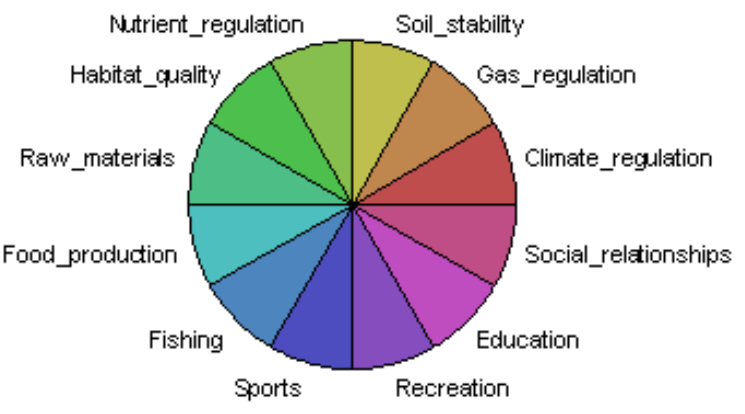


Table S1. Ecosystem services delivered based on the estimated proportion of each land use type at each spatial scale (patch, municipality and landscape). (Abbreviations: $\mathrm{AC}=$ abandoned crops; $\mathrm{DC}=\mathrm{dry}$ cereal crops; $\mathrm{FG}=$ fruit groves; $\mathrm{IC}=$ irrigated cereal crops; $\mathrm{PG}=$ poplar groves; $\mathrm{RF}=$ riparian forest; $\mathrm{UA}=$ urban areas).

\begin{tabular}{|c|c|c|c|c|c|c|c|c|c|c|c|c|c|}
\hline & & $\begin{array}{l}\text { Climate } \\
\text { regulation }\end{array}$ & $\begin{array}{l}\text { Gas } \\
\text { regulation }\end{array}$ & $\begin{array}{l}\text { Soil } \\
\text { stability }\end{array}$ & $\begin{array}{l}\text { Nutrient } \\
\text { regulation }\end{array}$ & $\begin{array}{l}\text { Habitat } \\
\text { quality }\end{array}$ & $\begin{array}{l}\text { Raw } \\
\text { materials }\end{array}$ & $\begin{array}{l}\text { Food } \\
\text { production }\end{array}$ & Fishing & Sports & Recreation & Education & $\begin{array}{l}\text { Social } \\
\text { relationships }\end{array}$ \\
\hline Scale & $\begin{array}{l}\text { Land } \\
\text { use }\end{array}$ & ${ }^{\circ} \mathrm{C}^{-1}$ & $\mathrm{CO}_{2}$ eqTons/Ha & $\mathrm{Cm}$ & Ppm & Score & Tons/Ha & $\mathrm{Kcal} / \mathrm{Ha}$ & $\mathrm{m}$ & $\mathrm{Ha}$ & Items & Items & Number \\
\hline \multirow{7}{*}{ Patch } & $\mathrm{AC}$ & 0,015 & 0,637 & 0,303 & 0,066 & 13,423 & 1,169 & 0,000 & 5,486 & 0,415 & 0,000 & 0,000 & 0,034 \\
\hline & $\mathrm{DC}$ & 0,009 & 0,000 & 0,049 & 0,037 & 7,357 & 0,453 & 1589132,782 & 0,124 & 0,775 & 0,000 & 0,000 & 0,183 \\
\hline & FG & 0,004 & 9,198 & 0,029 & 0,014 & 2,190 & 5,298 & 259907,184 & 0,001 & 0,010 & 0,001 & 0,000 & 0,056 \\
\hline & IC & 0,004 & 0,000 & 0,033 & 0,011 & 2,750 & 3,040 & 1695297,085 & 2,803 & 0,251 & 0,000 & 0,000 & 0,080 \\
\hline & PG & 0,006 & 3,264 & 0,073 & 0,015 & 3,687 & 1,393 & 0,000 & 0,373 & 0,128 & 0,001 & 0,000 & 0,039 \\
\hline & $\mathrm{RF}$ & 0,011 & 27,372 & 0,258 & 0,071 & 15,901 & 15,842 & 0,000 & 3,356 & 3,685 & 0,936 & 0,144 & 0,052 \\
\hline & UA & 0,004 & 0,000 & 0,000 & 0,000 & 0,456 & 0,000 & 0,000 & 0,178 & 0,081 & 0,003 & 0,002 & 0,015 \\
\hline \multirow{7}{*}{ Municipality } & $\mathrm{AC}$ & 0,000 & 0,021 & 0,010 & 0,002 & 0,434 & 0,038 & 0,000 & 0,177 & 0,013 & 0,000 & 0,000 & 0,001 \\
\hline & $\mathrm{DC}$ & 0,019 & 0,000 & 0,112 & 0,083 & 16,636 & 1,023 & 3593165,719 & 0,281 & 1,753 & 0,000 & 0,000 & 0,413 \\
\hline & FG & 0,005 & 12,210 & 0,039 & 0,019 & 2,907 & 7,032 & 345005,039 & 0,001 & 0,014 & 0,001 & 0,000 & 0,074 \\
\hline & $\mathrm{IC}$ & 0,010 & 0,000 & 0,089 & 0,029 & 7,329 & 8,102 & 4518511,742 & 7,472 & 0,669 & 0,000 & 0,000 & 0,212 \\
\hline & PG & 0,002 & 1,297 & 0,029 & 0,006 & 1,465 & 0,553 & 0,000 & 0,148 & 0,051 & 0,001 & 0,000 & 0,016 \\
\hline & $\mathrm{RF}$ & 0,003 & 6,360 & 0,060 & 0,016 & 3,694 & 3,681 & 0,000 & 0,780 & 0,856 & 0,217 & 0,033 & 0,012 \\
\hline & UA & 0,003 & 0,000 & 0,000 & 0,000 & 0,401 & 0,000 & 0,000 & 0,157 & 0,071 & 0,002 & 0,002 & 0,013 \\
\hline \multirow{7}{*}{ Landscape } & $\mathrm{AC}$ & 0,001 & 0,045 & 0,021 & 0,005 & 0,950 & 0,083 & 0,000 & 0,388 & 0,029 & 0,000 & 0,000 & 0,002 \\
\hline & $\mathrm{DC}$ & 0,020 & 0,000 & 0,118 & 0,088 & 17,660 & 1,087 & 3814539,896 & 0,299 & 1,861 & 0,000 & 0,000 & 0,439 \\
\hline & FG & 0,005 & 12,700 & 0,041 & 0,020 & 3,023 & 7,315 & 358857,140 & 0,001 & 0,014 & 0,001 & 0,000 & 0,077 \\
\hline & IC & 0,007 & 0,000 & 0,060 & 0,020 & 4,896 & 5,413 & 3018947,437 & 4,992 & 0,447 & 0,000 & 0,000 & 0,142 \\
\hline & PG & 0,003 & 1,807 & 0,040 & 0,008 & 2,042 & 0,771 & 0,000 & 0,206 & 0,071 & 0,001 & 0,000 & 0,022 \\
\hline & $\mathrm{RF}$ & 0,002 & 5,008 & 0,047 & 0,013 & 2,909 & 2,898 & 0,000 & 0,614 & 0,674 & 0,171 & 0,026 & 0,009 \\
\hline & UA & 0,005 & 0,000 & 0,000 & 0,000 & 0,617 & 0,000 & 0,000 & 0,242 & 0,109 & 0,004 & 0,003 & 0,020 \\
\hline
\end{tabular}


Table S2. Comparison across spatial scales of the supply of ES per hectare by each land use type. See Fig. S2 for details.

\begin{tabular}{ll}
\hline Scale & Sumary \\
\hline Patch & Riparian forest was the land use supplying most ES per hectare and with the highest \\
& values per hectare: gas regulation, nutrient regulation, habitat quality, raw materials, \\
& sports, recreation and education. Abandoned crops supplied the most climate regulation, \\
& soil stability and fishing areas, irrigated cereal crops produced the most part of food \\
& whereas dry cereal crops comprised most social relationships. \\
Municipality & Dry cereal crops were the main supplier of climate regulation, soil stability, nutrient \\
& regulation, habitat quality, sports and social relationships per hectare; fruit groves \\
& supplied the most of gas regulation; irrigated cereal crops supplied the most of food, raw \\
& materials and fishing; and riparian forest was the main supplier of recreation and \\
& education per hectare. \\
& Most ES per hectare were supplied by dry cereal crops (climate regulation, soil stability, \\
& nutrient regulation, habitat quality, food production, fishing areas, sports and social \\
& relationships). Minor contributors were riparian forests (recreation and education), fruit \\
& groves (gas regulation and raw materials).
\end{tabular}


Table S3. Significant factors in the supply of ES per hectare across three spatial scales. Significance codes: ‘***' for 0 ; ‘**' for 0.001 ; ‘ ' ' for 0.01 ; ‘' for 0.05 .

\begin{tabular}{|c|c|c|c|c|c|}
\hline Ecosystem service & Term & Chisq & Df & $\operatorname{Pr}(>$ Chisq $)$ & Significance \\
\hline \multirow[t]{3}{*}{ Climate regulation } & Land use & 0,34 & 6 & 1,00 & \\
\hline & Scale & 0,00 & 2 & 1,00 & \\
\hline & Land use-Scale & 0,27 & 12 & 1,00 & \\
\hline \multirow[t]{3}{*}{ Gas regulation } & Land use & 85,83 & 6 & $2,23 \mathrm{E}-16$ & $* * *$ \\
\hline & Scale & 25,77 & 2 & $2,53 \mathrm{E}-06$ & $* * *$ \\
\hline & Land use-Scale & 39,91 & 12 & $7,46 \mathrm{E}-05$ & $* * *$ \\
\hline \multirow[t]{3}{*}{ Soil stability } & Land use & 6,71 & 6 & 0,35 & \\
\hline & Scale & 5,03 & 2 & 0,08 & \\
\hline & Land use-Scale & 14,60 & 12 & 0,26 & \\
\hline \multirow[t]{3}{*}{ Nutrient regulation } & Land use & 4,71 & 6 & 0,58 & \\
\hline & Scale & 0,56 & 2 & 0,76 & \\
\hline & Land use-Scale & 3,41 & 12 & 0,99 & \\
\hline \multirow[t]{3}{*}{ Habitat quality } & Land use & 177,97 & 6 & $<2 \mathrm{e}-16$ & $* * *$ \\
\hline & Scale & 2,64 & 2 & 0,268 & \\
\hline & Land use-Scale & 116,60 & 12 & $<2 \mathrm{e}-16$ & $* * *$ \\
\hline \multirow[t]{3}{*}{ Raw materials } & Land use & 81,36 & 6 & $1,87 \mathrm{E}-15$ & $* * *$ \\
\hline & Scale & 5,77 & 2 & 0,06 & . \\
\hline & Land use-Scale & 41,11 & 12 & $4,70 \mathrm{E}-05$ & $* * *$ \\
\hline \multirow[t]{3}{*}{ Food production } & Land use & 1,10 & 10 & 1,00 & \\
\hline & Scale & 27,16 & 6 & 0,00 & $* * *$ \\
\hline & Land use-Scale & 0,16 & 12 & 1,00 & \\
\hline \multirow[t]{3}{*}{ Fishing } & Land use & 56,92 & 6 & $1,90 \mathrm{E}-10$ & $* * *$ \\
\hline & Scale & 2,86 & 2 & 0,24 & \\
\hline & Land use-Scale & 24,21 & 12 & 0,02 & $*$ \\
\hline \multirow[t]{3}{*}{ Sports } & Land use & 23,31 & 6 & 0,00 & $* * *$ \\
\hline & Scale & 0,57 & 2 & 0,75 & \\
\hline & Land use-Scale & 7,83 & 12 & 0,80 & \\
\hline \multirow[t]{3}{*}{ Recreation } & Land use & 0,58 & 8 & 1,00 & \\
\hline & Scale & 2,57 & 4 & 0,63 & \\
\hline & Land use-Scale & 0,02 & 12 & 1,00 & \\
\hline \multirow[t]{3}{*}{ Education } & Land use & 0,19 & 8 & 1,00 & \\
\hline & Scale & 0,31 & 4 & 0,99 & \\
\hline & Land use-Scale & 0,01 & 12 & 1,00 & \\
\hline \multirow[t]{3}{*}{ Social relationships } & Land use & 4,03 & 6 & 0,67 & \\
\hline & Scale & 0,22 & 2 & 0,90 & \\
\hline & Land use-Scale & 0,52 & 12 & 1,00 & \\
\hline
\end{tabular}


Fig. S2. Comparison in the supply of ES per hectare by each land use at three different spatial scales: patch, municipality and landscape. Horizontal axis shows land uses and vertical axis shows ES indicators (numbers express relative values per hectare). Lines are provided to improve scale differentiation. Note that most ES were delivered at patch scale, and only food production and social relationships were supplied mainly at municipality scale. Abbreviations: $A C=$ abandoned crops; $\mathrm{DC}=$ dry cereal crops; $\mathrm{FG}=$ fruit groves; $\mathrm{IC}=$ irrigated cereal crops; $\mathrm{PG}=$ poplar groves; $\mathrm{RF}=$ riparian forest; $\mathrm{UA}=$ urban areas.
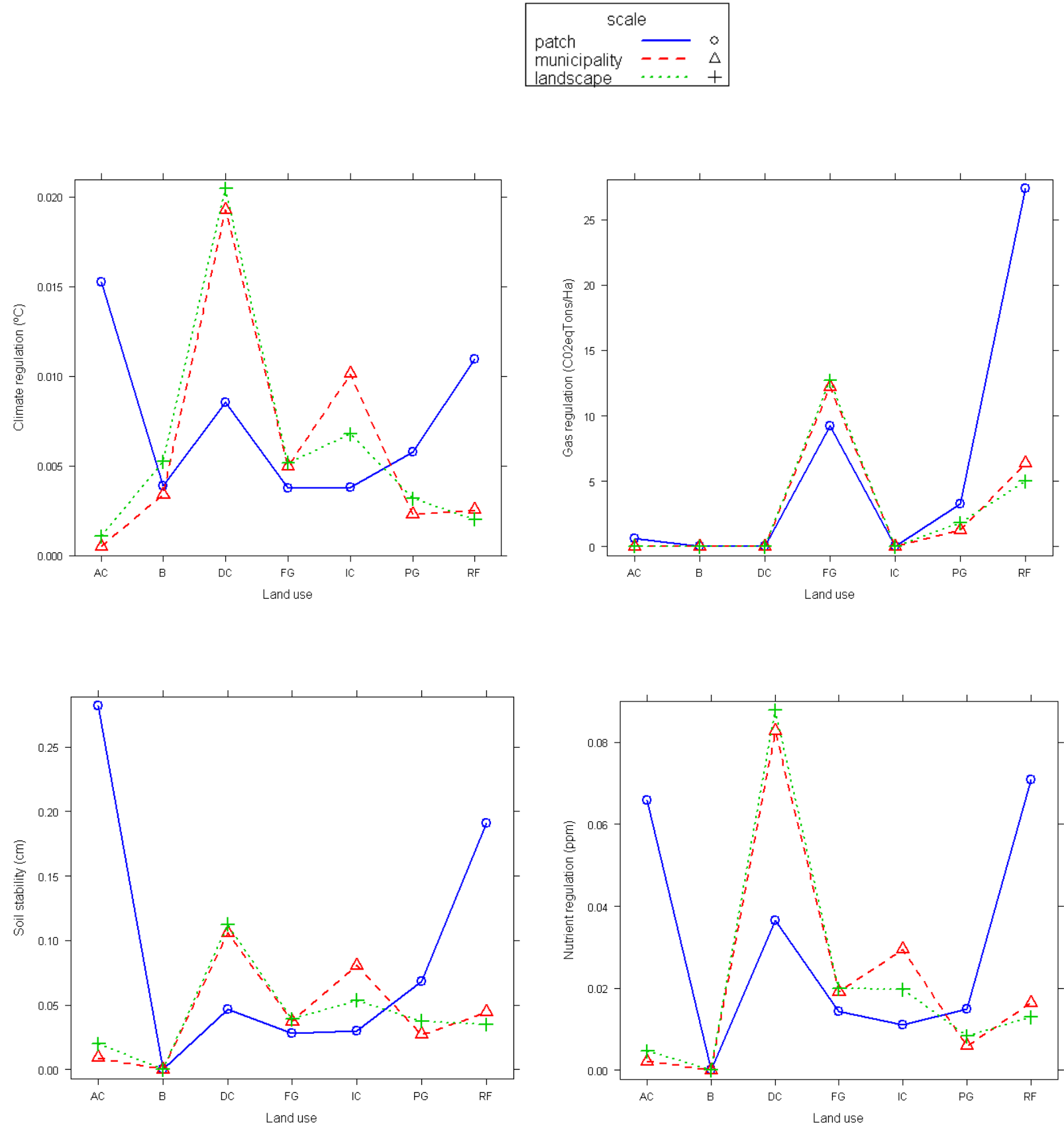

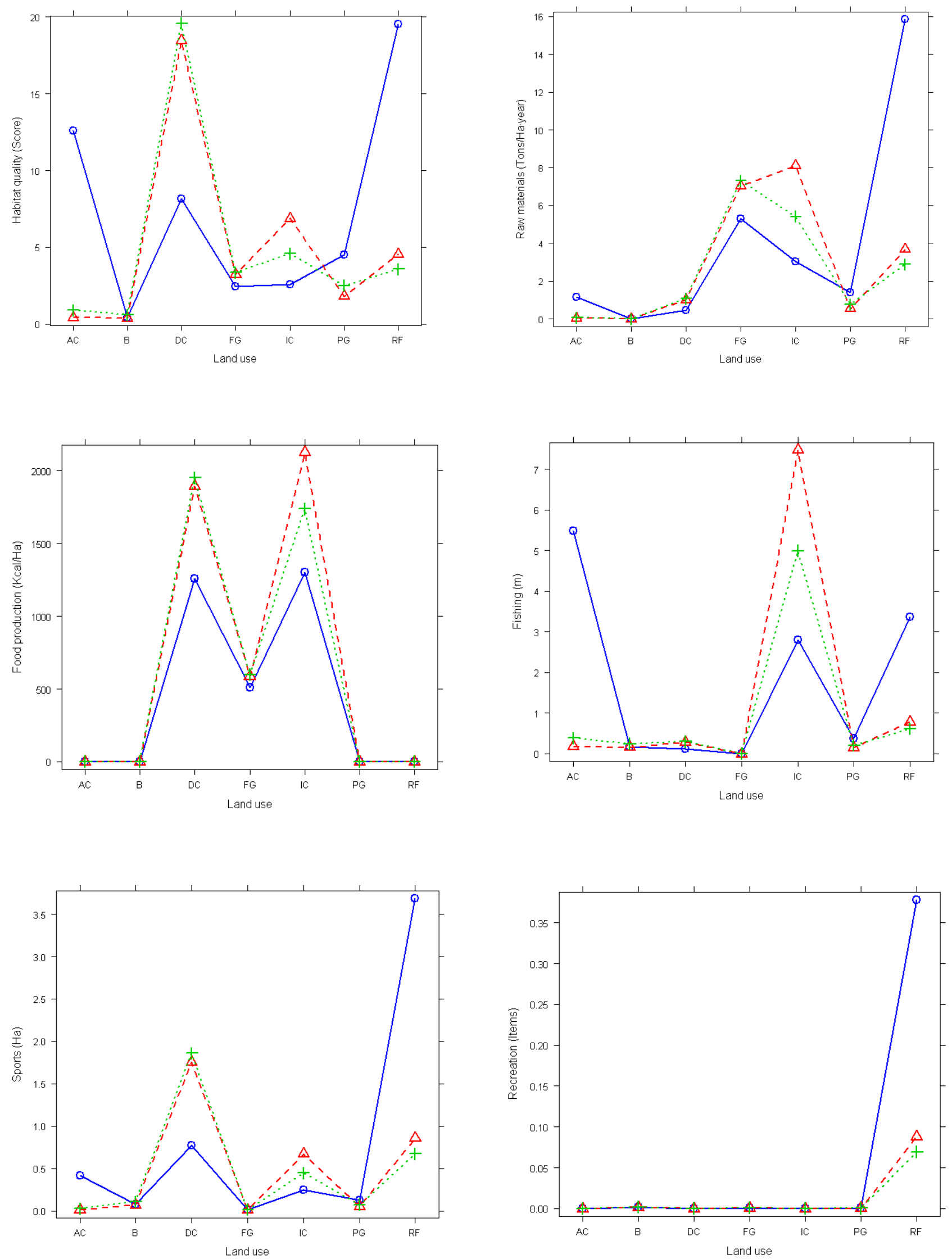

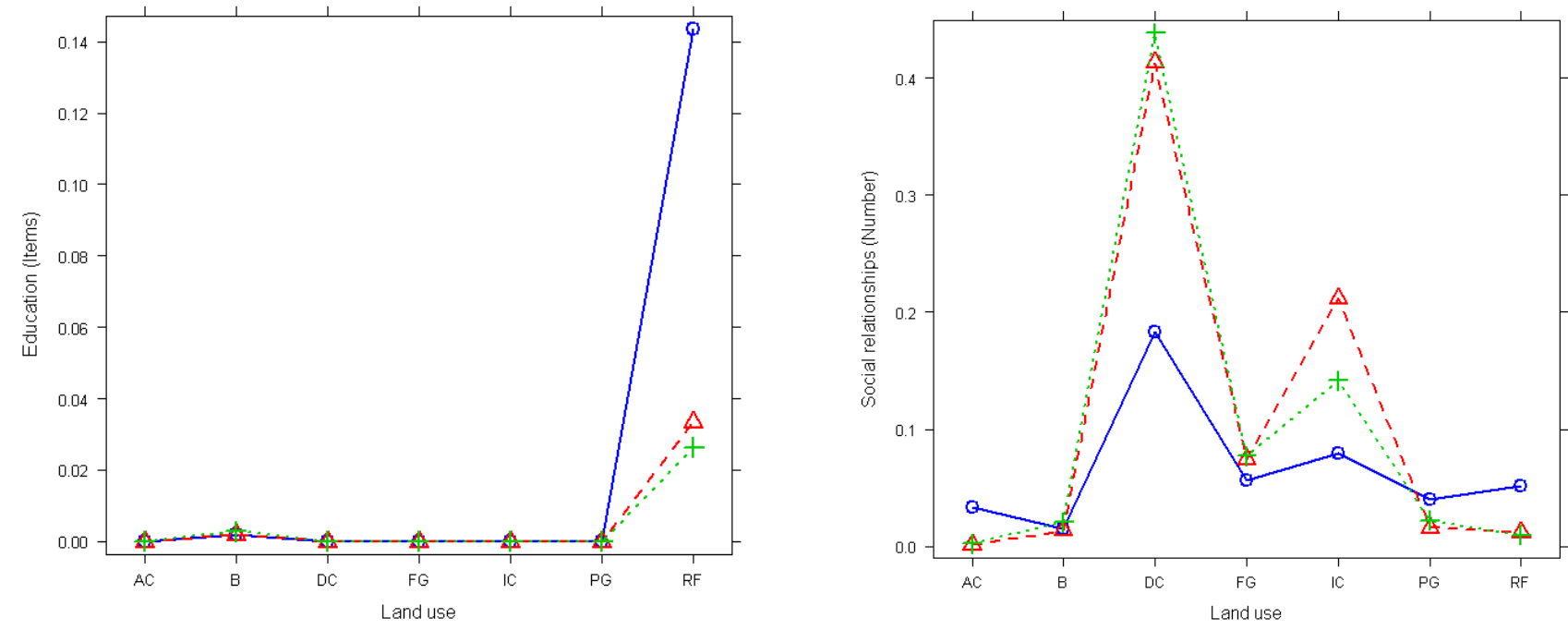